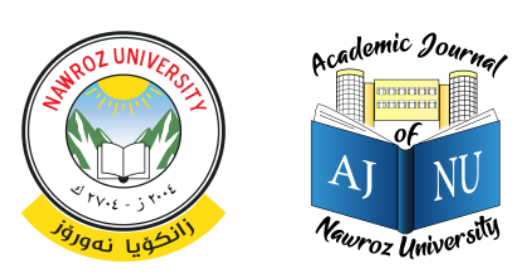

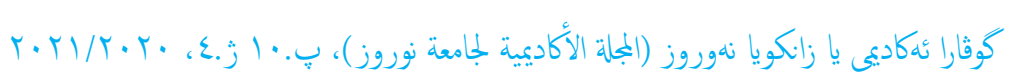
حقوق الطبع والنشر (2017. هذه مقالة الوصول اليها مفتوح موزعة تحت رخصة e-ISSN: 2520-789X ،CC BY-NC-ND 4. 0.

https://doi.org/10.25007/ajnu.v10n4a1297

\title{
المسؤولية المدنية عن أضرار البناء المتجاوز على أراضي الدولة "دراسة تحليلة مقارنة"
}

\author{
آرام ابلحد منصور، قسم القانون، جامعة دهوك ، إقليم كوردستان العراق \\ أ.م.د. عبدالله فاضل حامد، قسم القانون، جامعة دهوك، إقليم كوردستان العراق
}

تعتبرالأرض ثروة في غاية الأهية كنها تشكل إقليم الدولة الذي هو ركن من أركانها، وتمثل في ذات الوقت قيمة إقتصادية كبيرة لحياة الشعوب، وأعطت القوانين بشكل عام أولوية خاصة لتنظيها وتحديد

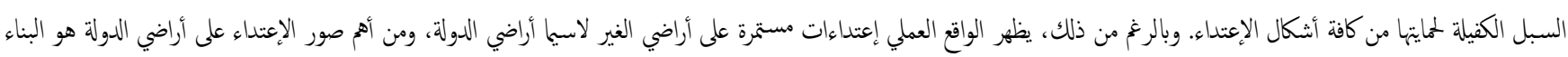

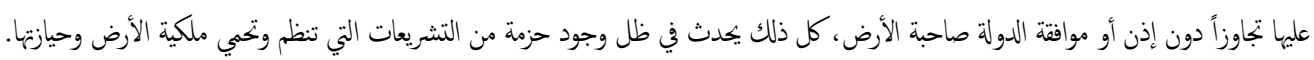

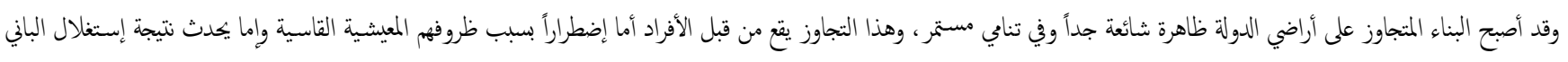

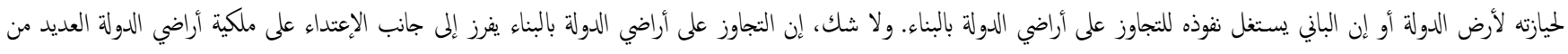
الأضرار الأخرى والتي تصيب الأفراد العاديبن كإنتشار البناء العشوائي في مراكز المدن وخالفة ضوابط التخطيط العراني، كما إن البناء المتجاوز في حال إقتاهه من قبل الباني يثير العديد من المشاكل

القانونية المتعلقة بصير البناء المقام على أرض الدولة والمسؤولية المدنية والجنائية المترتبة على الباني تجاوزاً.

القانون وتفشي ظاهرة الفساد الإداري. ولا شك، إن التجاوز على أراضي الدولة

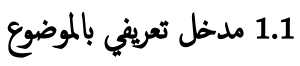
بالبناء سيفرز إلى جانب الإعتداء على ملكية أراضي الدولة العديد من الأضرار تعد الأرض من الأموال الهامة والأساسية في حياة الشعوب والمجتمعات فهي الأخرى والتي تصيب الأفراد العادين كإنتشار البناء العشوائي في مراكز المدن وخخالفة ضوابط التخطيط العمراني، كما إن البناء المتجاوز في حال إتمامه من قبل الباني سيثير العديد من المشاكل القانونية المتعلقة بصير البناء المقام على أرض الدولة والمسؤولية المدنية المترتبة على الباني تجاوزاً.

2.1 لا شك إن واقعة البناء على أراضي الدولة تجاوزاً يشكل عملاً غير مشروع وإعتداء على حق الدولة في ملكيتها للاراضي، وهذه الواقعة غير المثروعة تثير ، إضافة إلى المسؤولية الجزائية للباني، المسؤولية المدنية عن عمله غير المشروع، تتجلى أهمية البحث نظريا في محاولة تأصيل المسؤولية المدنية للباني المتجاوز على أراضي الدولة بالبناء، فكما هو معلوم ان المسؤولية المدنية لا تقام إلا بتوافر أركانها

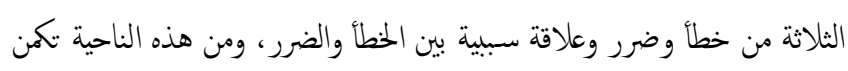
أهمية البحث في تشخيص أركان المسؤولية المدنية عن واقعة البناء المتجاوز على ولى أراضي الدولة. وإذا ما تحققت أركان المسؤولية فإن التساؤل الذي يثار بعد ذلك الك تشكل إقليم الدولة وهي محل لمارسة السيادة، فن أجلها إندلعت الحروب وفي سبيل الدفاع عنها أريقت الدماء. فالأرض كانت ولا تزال تمثل القيمة الإقتصادية الأولى للإنسان، ولذلك أعطت القوانين القديمة والحديثة أولوية خاصة لتنظمها وتحديد السبل الكنيلة لممايتها من كافة أشكل الإعتداء. وبالرغز من ذلك، يظهر الواقع العملي في دول عديدة - ومنها العراق واققليم كودستان العراق- شيوع حالات الإعتداء على أراضي الغير لاسيا أراضي الدولة، ومن أهم صور الإعتداء على أراضي الدولة هو البناء عليها تجاوزاً دون إذن أو موافقة الدولة صاحبة الأرض ، ولعلنا لا نبالغ، إذا قلنا إن التجاوز على أراضي الدولة بالبناء أصبح أمراً

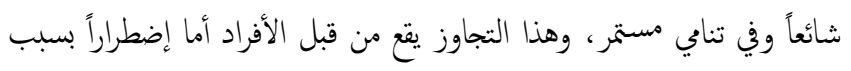
ظروفهم المعيشية القاسية وعدم مقدرته على إمتلاك وحدة سكنية بالطرق المثروعة، وإما يحدث نتيجة إستغلال الباني لحيازته لأرض الدولة وفق سند قانوني كميازة المتصرف لأرض الدولة للأغراض الزراعية أو إن الباني يستغل نقوذه السياسي والإداري للتجاوز على أراضي الدولة بالبناء في ظل غياب سيادة 


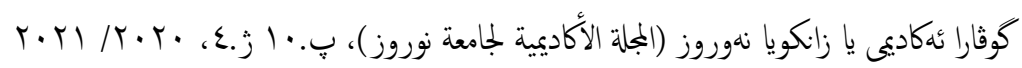
مباشرة هو المكم القانوني لمسؤولية الباني المدنية، ومن هذه الناحية تكمن أهمية البحث في حكم المسؤلية المدنية للباني المتجاوز وصور جبر الضرر الناتج عن فعله.

\section{1 فرضيات البحث}

إن أراضي الدولة يسهل التجاوز عليها بالبناء قياساً على الأرض المملوكة ملكية خاصة ولعل السبب في ذلك هو إن مالك الأرض هو شخص معنوي (الدولة ومؤسساتها) وكلما ضعفت الدولة سياسياً وإدارياً كلما كثرت حالات التجاوز على سلى أراضي الدولة بالبناء، كما إن قساً من أراضي الدولة لها صفة المال العام والذي يعني إن حرمة هذا المال من الإعتداء والتجاوز بالبناء وغيره مضاعفة قياساً على سلى الأرض المملوكة ملكية خاصة، ومع ذلك لا هذه الصفة ولا تلك الحرمة يبدو إنها يحولان دون التجاوز على أرض الدولة بالبناء. كما يفترض البحث إحثفاظ الدولة

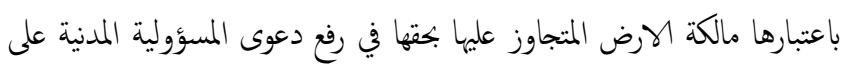
الباني المتجاوز إضافة إلى الغير من الأشخاص العاديين الذين أصاهم الضرر من واقعة البناء المتجاوز.

6.1

سنتبع في هذا البحث، المنهج التحليلي من خلال تحليل النصوص التشريعية والأحكام القضائية المتعلقة بالتجاوزات على أراضى الدولة بالبناء إضافة إلى تناولنا بالتحليل لموقف الفقه القانوني من الموضوع محل الدراسة. كما سنتبع المنهج المقارن من خلال مقارنة موقف القانون العراقي من المسؤولية المدنية للباني المتجاوز على أراضي الدولة مع موقف بعض التشريعات العربية كالقانون المصري والجزائري من

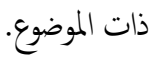

\section{1 هيكلية البحث}

سنقسم البحث على مبحثين سنتناول في المبحث الأول أركان المسؤولية المدنية عن البناء المتجاوز أما المبحث الثاني فسنتناول فيه أحكام المسؤولية المدنية عن البناء المتجاوز على أراضي الدولة، على ان يسبق ذلك مطلب تمهيدي في بيان

$$
\text { مفهوم البناء المتجاوز. }
$$

\section{2. مطلب تمهيدي: في مفهوم البناء المتجاوز}

البناء لغة مصدره بنى الشيء، بنى بيتاً وبنى على أهله يبنى زفها، وبناء وبنيان

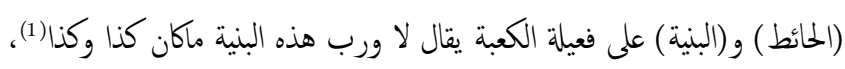
والمبنى هو المفرد، والجمع هو أبنية وبمع الجمع البنايات ويستعمل مجازاً في معنى

$$
\text { التنمية والتأسيس فيقال بنى على كلامه: إحتداه وإعتمد عليه (2). }
$$

أما عمليا، فإن أهية البحث ثكمن في تبصير رجال القانون والقضاء بأحكام المسؤولية المدنية للباني المتجاوز إضافة إلى وضع النصوص التشريعية ذات العلاقة على مشرحة التحليل والدراسة بهدف تقيهها وتشخيص نتص محتل.

\section{1 أسباب إختيار موضوع البحث}

يرجج إختيارنا للبحث في المسؤولية المدنية للباني المتجاوز على أراضي الدولة إلى شيوع ظاهرة البناء المتجاوز على أراضي الدولة في ظل قواعد قانونية عامة تؤكد حرمة حق الملكية وتنع جميع أشكال الإعتداء عليها، إضافة إلى وجود قواعد قانونية خاصة تنع البناء على أراضي الدولة وتضضي بازالة القائم منها، فالذي دفعنا في البحث في هذا الموضوع هو تشخيص الحلقة المفتودة ألتي تربط بين صراحة القواعد القانونية العامة والخاصة في منع التجاوز وإزالته وتناي حركة التجاوز بالبناء على أراضي الدولة حتى باتت تشكل ظاهرة غير قانونية. وكذلك البحث في

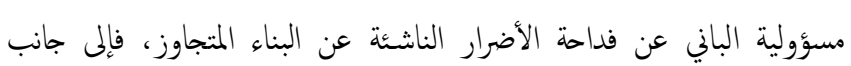
الأضرار اللاحقة بملكية الدولة للأرض تتعدى الأضرار إلى أضرار زراعية متثثلة في قضم الأراضي الزراعية في أطراف المدن ، وإلى بروز أحياء عشوائية في أطراف المدن تثتقد إلى خدمات المرافق العامة من صحة وتعليم ومياه وطرق.

4.1 مشكة البحث

ثكن مشكلة الموضوع في إن البناء المتجاوز على أراضي الدولة لازال مستمراً على قدم وساق، رغز القوانين والقرارات ألتي تصدر بين الحين والأخر لمنع التجاوز وإزالة القائم منها. وهذه يعني من ناحية، قوة الأسباب الدافعة إلى التجاوز على نحو يقف القانون عاجزاً عن القضاء على ظاهرة البناء المتجاوز لاسيا في مركز المدن الكبيرة. ومن ناحية أخرى، يعني إن الحكومة متقاعسة عادة عن أداء واجها الدستوري المتمثل فسي ضمان السكن الملائم لكل مواطن عراقي، أو إنها متقاعسة عن محاسة من تجاوز بالبناء إستغلالاً لحيازته أو نقوذه وهذا في نظرنا يحمل المكومة ذاتها جزء من مسؤولية البناء المتجاوز على أراضي الدولة. ومع ذلك، فإن المسؤولية المدنية للباني عن واقعة البناء المتجاوز تبقى قائمة بغض النظر عن الأسباب ألتي تقق وراء تجاوزه، علما ان مبدأ العدالة يقتضي التمييز بين المتجاوزين على نو تخفق مسؤولية المضطر وأن يسأل غير المضطر عن اعتدائه مسؤولية كاملة. 


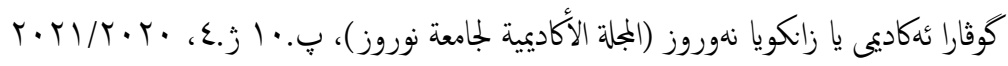

مما سبق، يظهر لنا إن البناء المتجاوز هو البناء الذي يقام على أرض مملوكة للدولة بدون وجه قانوني، وإن واقعة البناء التي تقع على أراضي الدولة تجاوزاً عليها لا تعد إلا صورة من صور التجاوز على الأراضي العائدة للدولة، فقد يقع التجاوز بدون البناء أيضاً كلتصرف في أراضي الدولة بالبيع وغير ذلك، وينصرف مفوم البناء المتجاوز إلى البناء الحديث الذي يتم لأول مرة على الأرض وليس البناء المتجاوز الذي يقع على بناء مشييد مسبقاً مملوك للدولة لأن هذه الأخيرة تندرج تحت التجاوز على المرافق العامة للادولة أو على مباني أو منشآة الدولة.

\section{2 المبحث الاول: أركان المسؤولية المدنية عن البناء المتجاوز على أراضي الدولة}

يترتب على نشاط الأفراد داخل المجتع في بعض الحالات قيام مسؤوليتهم عن ذلك

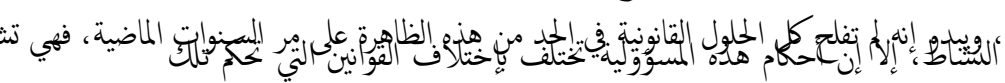
المسؤولية، فإن كانت المسؤولية تقررها القوانين الجنائية فإنها في هذه الحالة تصبح مسؤولية جنائية وإن كانت تقررها القوانين المدنية تكون المسؤولية مدنية، والمسؤولية الأخيرة بدورها تنقسم إلى مسؤولية عقدية ناشئة عن إخلال بإلتزام عقدي ومسؤولية تقصيرية ناشئة عن الإخلال بإلتزام قانوني والمتمثل في الإلتزام بعدم الإضرار بالغير. ولقد نصت الفقرة الأولى من المادة (186) من القانون المدني العراقي على إنه (إذا أنلف أحد مال غيره أو أنص من قيمنه مباشرة أو تسببا يكون ضامنا إذا كان في إحداثه هذا الضرر قد تعمد أو تعدى)، كما إن المادة (204) نصت على إن (كل تعد يصيب الغير بأي ضرر آخر غير غير ماذكر في المواد السابقة يستوجب التعويض). ويلاحظ من نص هذه المادة إن القانون لم يكصر صور الخطأ أو الحالات التي تستوجب التعويض وإنما جعل الباب مفتوهاً لعدم توقع الأخطاء التي قد تنجج عها ألاضرار، وبالنالي فإن المسؤولية التقصيرية

تقوم كلماكان هناك خطأ وضرر مع وجود علاقة سبية بنهها. ويجدر بالذكر، إن المسؤولية التقصيرية تطورت بشكل كير في نطاق القانون الخاص ويرجع السبب في ذلك إلى زيادة أنشطة الأفراد في كافة مجالات الحياة وتطورها من الناحية الإقتصادية والإجتاعية، ويبدو ان التطور الذي حصل في قواعد المسؤولية التقصيرية يتجه عادة نخو الإخياز إلى جانب المتضرر من خلال إعطائه التعويض المستحق جراء الضرر الذي أصابه من خلال تسهيل إثبات الخطأ وبإفتراضه أحياناً وصولاً إلى حلات تقوم المسؤولية فيها على أساس الخطر ، وقد نص القانون المدني العراقي على المسؤولية التقصيرية في المواد من (186232)، ولا يخنى إن المسؤولية المدنية عن أي خرق لواجب قانوني لا تقوم إلا إذا
أما تعريف البناء في التشريع العراقي، فقد ورد ذكر البناء في الفقرة (1) من المادة (62) من القانون المدني العراقي كثال على العقار ، فجاء فيها أن (العقار كل شيء له مستقر ثابت بحيث لا يككن نقله أو تحوياه دون تلف فيشمل الارض والبناء والغراس والجسور والسدود والمنابم وغير ذلك من الاشياء العقارية). أما تعريف ترك ترك البناء كمملية تشييد فقد ورد في الفقرة (ب) من المادة (1) من نظام الطرق والابنية العراقي رقٌ (44) لسنة 1935 وألتي نصت على إن البناء هو(كل انشاء جديد (ويشمل حفر الاساس) أو ترميم بمادة واحدة أو أكثر من مواد الإنشاء سواء كان معروفاً إستعالها أو غير معروف وكل بياض وتطبيق واقامة ستارة أو مظلة على وابجة الطريق أو محركات وما يماثل ذلك)(3). البناء المتجاوز هو ظاهرة في نمو متزايد في العديد من الدول ومنها العراق وإقليم كوردستان الدولة من غير إضطرار أي إستغلالاً للنفوذ السياسي أو الإجتاعي يقع تحت حكم هذه المادة، أما البناء المشـيد إضطرار على أراضي الدولة دون موافقات فتشكل معضلة قانونية حقيقية تحتاج إلى معالجها بقوانين خاصة. وقد ذكر قرار مجلس قيادة الثورة المنحل رقٌ (154) لسـنة 2001، المتعلق بتحديد التصرفات التي تعـد تجاوزاً على العقارات العائدة للدولة والبلاديات، في المادة (أولاً) التصرفات التي تقع على العقارات العائدة للدولة والبلديات ضمن حدود التصاميم الأساسية للمدن ودون الحصول على موافقة أصولية من قبيل التجاوز ومنها البناء سواء أكان موافقاً أم خخالفاً للتصاميم الأساسية للمدن (4)، ووفقا لمصطلحات قانون التسجيل العقاري العراقي فإن البناء المتجاوز هو (تعدي حدود عقار الغير بصورة غير مشروعة)(5). فالبناء المتجاوز واقعة مادية تنمثل بتشييد بناء يؤدي إلى إتلاف أو تشويه متعمد وغير متعمد لبنية المدينة ككان حضري ومكونات هذا المكان وعناصره، مما يؤدي إلى تغير صورته التي ينبني أن تكون عليها أو ينبغي الظهور بهاب(6)، ويتم ذلك عبر الإستيلاء على الأراضي المملوكة للدولة وإستغلالها بالبناء خلافاً لما جاء به التصميم الأساس حسب القوانين النافذة(7). ويجدر بالذكر ، ان قانون منع وإزالة التجاوز على أراضي الدولة في إقليم كردستان العراق رقٌ (3) لسـة 2018 لم يعرف البناء المتجاوز بشكل واضح وقد نصت الفقرة (أولاً) من المادة (4) على انه (يعد تجاوزاً كل تصرف أو عمل يرد على أراضي الدولة ...) ومن جملة هذه التصرفات والأعمال تشـيد المنـازل والأبنيـة بمختلف أنواعهـا وأغراضها سـواء كان موافقـاً للتصـاميم الأساسية أم خخالفاً لها وكذلك شمل الأراضي التي تقع خارج حدود البلديات، وقد أحسن المثرع الكوردستاني عندما شمل كل هذه الحالات بالتجاوز ولم يدع أي

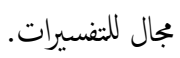




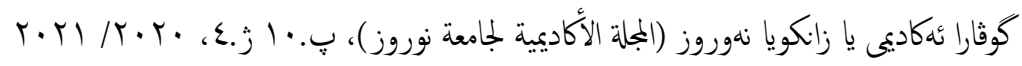

الإخلال بواجب قانوني سابق مقترن بإدراكـ بهذا الهخلال ودون قصد الإضرار بالغير، فالخطأ في هذه الحالة يرتكبه الشخص بدون نية الحاق الضرر بالغير وإنما يصدر عن إهال فاعله أو عدم تبصره، وعلى هذا الأساس قسم المثرع الفرني الفعل الضار إلى جريمة وشبه الجريمة(10). أما العنصر الثاني فهو معنوي يتمثل ب(التمييز والإدراك) إذ لا يكني لقيام الخطأ وجود التعدي فقط إنا يجب أن يكون هذا التعدي مصحوباً بتمييز الفاعل بين الخطأ والصواب، وهذا يعني عدم إمكانية إعتبار الشخص مخطئًا إستناداً إلى عنصر التعدي فقط بل يجب أن يتوافر أيضاً الركن المعنوي المتثثل بالإدراك (11). ويتحقق الخطأ في واقعة البناء المتجاوز بشكل

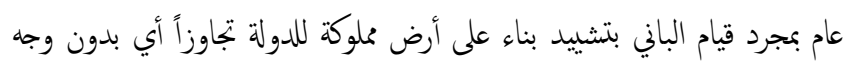
حق، سواءكانت هذه الأرض مملوكة للدولة ملكية عامة أو ملكية خاصة وسواء

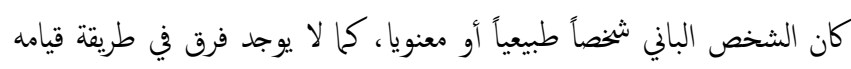
بالبناء سواء تمثل بمجرد مستحدثات صغيرة أو بناء كثك أو أبنية كيرة كالعهارات أو أياًكان الغرض منه مادام يدخل في مفهوم البناء. فالإلتزام القانوني هنا يتثل في تئي عدم التعدي بالبناء على أراضي الدولة، وبالتالي فكل شخص يتعدى بالبناء المتجاوز على أراضي الدولة يكون قد إخرف بسلوكه وخرق واجباً قانونياً وبالتالي يتحقق ركن الخطأ أو النعدي من خلال البناء على أراضي الدولة بدون حق، وفي معظم الأحوال يكون الباني مدركا إنه يتعدى على أراضي الدولة، كما إن الخطأ

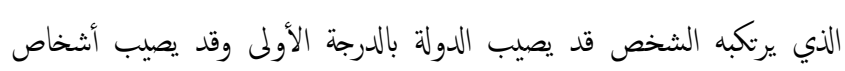
آخرين.

\subsubsection{2 الفرع الثاني: صور الخطأ في البناء المتجاوز على اراضي الدولة}

تتعدد صور الخطأ الذي يرتكبه المتجاوز على أراضي الدولة بالبناء ويكن تلخيص

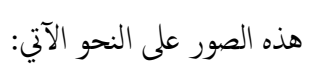

عدم الحصول على إجازة البناء، إن إجازة البناء تعتبر أولى الإلتزامات التي تقع على عاتق الباني عند تشييد البناء أو تغييره بغض النظر عن الغرض

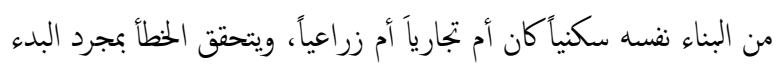
بعملية التشييد الذي يشكل السلوك المادي في جريمة البناء بدون إجازة، وهذه الجريمة تتحقق بسلوكين أولما سلوك إيجابي وهو فعل البناء وسلوك سلبي يتمثل الإمتناع عن الحصول على إجازة البناء(12)، وقد نصت المادة (63) من قانون إدارة البلديات العراقي رڤٌ (165) لسنة 1964 المعدل على إنه (لايجوز القيام بأي بناء قبل إستحصال إجازة البلدية)، وما يلاحظ
توافرت أركانها وهي الخطاً والضرر والعلاقة السبية بين الخطأ والضرر، وبإعتبار إن واقعة البناء على أراضي الدولة تجاوزاً تمثل خرقاً لحزمة من القوانين المتعلقة بالملكية والبناء والتخطيط العمراني، وفي الوقت ذاته يعد عملاً غير مشروع يرتب المسؤولية التقيرية للباني المتجاوز، لنلك فإن مسؤولية الباني المدنية يكن أن تثار عن واقعة البناء المتجاوز على أراضي الدولة بعد توافر أركان المسؤولية التقصيرية، وسوف نتسم هذا المبحث على مطلبين سنتناول في المطلب الاول ركن الخطأ في المسؤولية المدنية عن البناء المتجاوز أما في المطلب الثاني فسنتناول ركنا الضرر والعلاقة السببية.

\subsection{2 المطلب الأول: ركن الخطأ في المسؤولية المدنية عن البناء المتجاوز}

لا شك إن مجرد البناء على أرض الدولة دون إذن يعد خطأ وتعدياً على ملكية الدولة، إضافة إلى مخالفة واجبات قانونية همة بها الصدد كمخالفة قوانين البناء والتخطيط العمراني، وكذلك التعدي على حقوق الغير من الأفراد العادين كما في حقوق الملاك المجاورين للبناء المتجاوز، لذلك يتخذ الخطأ في المسؤولية المدنية عن البناء المتجاوز على أراضي الدولة صوراً عدة، لذلك ولأجل الإلمام بما سبق ذكه، سوف نقسم هذا المطلب على فرعين سنخصص الفرع الأول لتحديد المقصود بالخطأ في نطاق المسؤولية المدنية عن البناء المتجاوز على أراضي الدولة، وفي الفع الثاني سنتناول صور الخطأ في البناء المتجاوز على أراضي الدولة.

1.1.1.2 الفرع الأول: المقصود بالحطأ في نطاق المسؤولية المدنية عن البناء

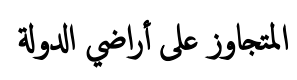

لقد إختلفت الآراء حول تعريف الخطأ في المسؤولية التقصيرية(8)، إلا انه يككن القول بأن الخطأ في المسؤولية التقصيرية هو إخلال بالتزام قانوني سابق، وهو التزام بإحترام حقوق الناس كافة وعدم الإضرار بهم، اما طبيعة هذا الالتزام فهو إلتزام ببذل عناية، وهذا يعني أن يصطنع الشخص في سلوكه اليقضة والتبصر حتى لا يضر بالغير فإذا إنخرف الشخص عن هذا الواجب المفروض عليه وكان ميزاً ويدرك إنه قد إخرف فإن هذا الإخراف في السلوك هو الخطأ الذي يستوجب المسؤولية التقصيرية، فكل تعد يصيب الغير بأي ضرر يستوجب النعويض (9). وللخطأ عنصران الأول مادي ويتمثل بـ (ألإخلال أو التعدي) والني بدوره قد يكون عمدياً حيث يرنكبه الفاعل بسوء نية وبقصد الحاق الضرر بالغير، فهو الإخلال بواجب قانوني مقترن بقصد الإضرار بالغير. أما الخطأ غير العمدي فهو 


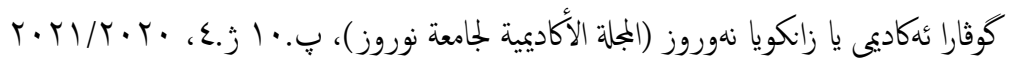

العلاقة العقدية الموجودة بين الحائز والدولة قد يكصل الحائز على إذن بالبناء في أرض الدولة إلا إنه يخالف شروط البناء المطلوبة قانوناً وبالتالي فيعتبر بذلك متجاوزاً بالبناء (13). التعدي على ملك الدولة، وهي إحدي صور الخطأ التي تتمثل في إنتهاك حرمة ملك الدولة بدون وجه حق وإنعدام المسوغ القانوني لهذا النعدي سواء وقع هذا التعدي على الأراضي المملوكة ملكية عامة للدولة والتي هي مخصة للنغع العام مثل الأسواق والميادين العامة أو تلك الأراضي المملوكة للادولة ملكية خاصة وهي بدورها تنقسم إلى الأراضي التي تكون خالية من حق التصرف أو قد تكون مثقلة بحق التصرف وهذه الاخيرة قد تكون لأغراض زراعية أو غير زراعية كإنشاء دور سكنية داخل البساتين خلافاً القوانين، أما المشرع في قانون العقوبات العراقي رقٍ (111) لسنة 1969 فإنه بسط حاية شاملة على أموال الدولة بشكل مطلق ولم يفرق بين أموال الدولة العامة أو الخاصة(14)، هذا وقد إعتبرت الفقرة (أولاً/2) من (4) من قانون منع وإزالة التجاوز على أراضي الدولة في إقليم كوردستان العراق تشييد المنازل والأبنية بمختلف أنواعها و أغراضها وسواء كانت موافقة اللتصاميم الأساسية للمدن أو خخالفة لها تجاوزاً. التعدي على البيئة، عرف المشرع العراقي البيئة بأهها ((الميط بجميع عناصره الذي يعيش فيه الكائنات الحية والتأثيرات الناجمة عن نشاطات الإنسان الإقتصادية والإجتاعية والثقافية)(15)، وقد نصت الفقرة (أولاً) من المادة (21) من قانون حاية وتحسين البيئة في إقليم كوردستان - العراق رقز

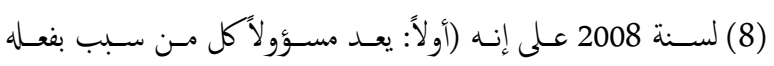
الشخصي أو إهـاله أو بفعل من هم تحت رعايته أو رقابته أو سيطرته من الأشخاص أو الإتباع أو مخالفته القوانين أو الأنظمة والتعليات ضرراً بالبيئة ويلزم بالتعويض وإزالة الضرر وإعادة الحال إلى ماكانت عليه قبل حدوث الضرر وضمن المدة المحددة من الوزارة وبالشروط الموضوعة من قبلها، وفي حال إهـاله أو إمتناعه عن القيام بذلك يجوز للوزارة بعد اخطاره إتخاذ الندابير والإجراءات الكفيلة بإزالة الضرر ويتحمل المسبب بجميع ما تكبدته كائه لهذا الغرض مضافأ اليه النفقات الإدارية...)(16) وكذلك نصت المادة (28) من القانون نفسه في الفقرة (ثالثاً) حظر إنشاء أو أقامة أي نشاط صناعي أو تجاري أو خدمي على الأراضي الزراعيـة خلافـا لاحكام القانون، كما
على هذه المادة إنها لم تحدد نوع وطبيعة البناء أو الأعال التي يقوم بها الباني وبالتالي فأنه يؤخذ على إطلاقه كما إن المشرع لم يحدد هل إن التزميم والنعلية يدخلان ضمن هذا المفووم أم لا؟، وهذا بخلاف موقف المثرع المصري في المادة (39) من قانون البناء المصري رقٌ (119) لسنة 2008 حيث نص على إنه (يخظر إنشاء مبان أو منشآت أو إقامة أعال أو توسيعها أو تعليتها أو تعديلها أو تدعيمها أو ترميها أو هدم المبانى غير الخاضعة لقانون هدم المبانى غير الآيلة للسقوط جزئيا أو كليا أو إجراء أي تشطيبات خارجية دون الحصول على ترخيص فى ذلك من الجهة الإدارية المختصة بشؤون التخطيط والتنظيم وفقا للإشتراطات البنائية وقت إصدار الترخيص ولما تبينه اللائحة التنفيذية لهذا القانون)، فكل الأعال المشار إلها في هذه المادة لا يمكن القيام بها دون ترخيص من الجهة الإدراية الختصة. وفي إقليم كوردستان- العراق، أعتبرت المادة (4) من قانون منع وإزالة التجاوز على أراض الدولة رڤٌ (3) لسنة 2018 تجاوزاً كل تصرف تم على أرض الدولة دون الحصول على ترخيص قانوني، وأول وما يلاحظ على هذه المادة إنها جاءت بكيم عام على كافة أنواع التجاوزات التي من الممكن تصورها على أراضي الدولة سواءكان بالبناء أو غيره، كما إنها جاءت بلفظ "النزخيص" بخلاف لفظ "الإجازة" المستخدم في القانون العراقي. البناء خلافأ لشروط إجازة البناء، وهذه هي إحدى صور الخطأ المرتكب من قبل الأشخاص في مجال البناء، وتتمثل بعدم الإلتزام بالشروط التصميمية للبناء والتي تحددها البلدية المعنية بعد إستحصال الإجازة المطلوبة لذلك، وهذه الشروط قد تكون فنية أو موضوعية. وعلى العموم فأياً كانت هذه الشروط فعلى القائم بعملية البناء الإلتزام بها وإلا إستوجب ذلك مسؤولية الباني الجنائية والمدنية بسبب مخالفته شروط الإجازة، لذلك نصت المادة (95مكررة1) من قانون إدارة البلديات العراقي على إنه (لمدير عام دائرة البلدية التابعة لأمانة بغداد ومدير البلدية الختص فرض غرامة مقدارها 25000 خمسة وعشرون الف دينار على كل من: أولا - اقام بناء او منشات سكنية بدون إجازة أصولية أو خلافا لها صادرة عن أمانة بغداد أو البلدية المختصة، ويكون كل من صاحب الملك والقائم بعملية البناء أو الاشراف عليها مسؤولا عن ذلك). ويككن تصور هذه الصورة من الخطأ في حالة الباني المتجاوز إستغلالاً لحيازته كالمتصرف والمساطح، فبحكي 


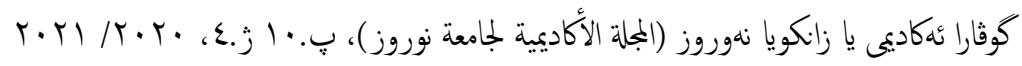

الدولة تشكل خرقاً لعدة قوانين متعلقة بالملكية والبناء والتخطيط العمراني، فإن صور الضرر تكون متعدد بالضرورة وسوف نتناولها كما يأتي:أولاً: الإخلال بالتخطيط العمراني: إن للتخطيط العمراني دور هام وبارز

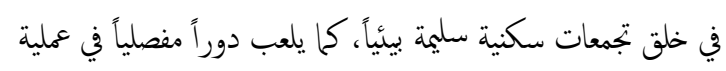
التنمية المستدامة(20)، وتعد الثورة الصناعية في أوروبا أبرز العوامل التي كانت سبباً للإهتمام بالتخطيط العمراني بسبب النزوح الكبير من الريف إلى كالى المدن مما تسبب في نمو عدد سكان المدينة بشكل كير وما تسببته من مشاكل كالنلوث البيئي والإكتظاظ السكاني وكذلك ظهور الأحياء العشوائية. والتخطيط بصفة عامة هو العملية التي يتم فهيا إستغلال الموارد البشرية والمالية من أجل تحقيق بموعة من الأهـداف وذلك من خلال إستخدام الأسـاليب العلميـة، وبالتـالي فهنـاك تخطيط إقتصـادي وتخطيط ثقافي وتخطيط إجتاعي وتخطيط تربوي وتخطيط عمراني ...الخ. وقد تعددت مسميات علم التخطيط العمراني خلال مراحل التطور الذي مر به، فكلئ يطلق عليه التخطيط الحضري أو تخطيط المدينـة أو تخطيط البلدة أو تخطيط الإقليم، والقوانين التي تنظم العمران بشكل عام هي آليات أساسية ومؤثرة في رفع مستوى جـال المـدن وتحسـين بينتهـا وبالتـالي الـرقي في التحضر - وأغلـب التشرـيعات العربيـة تحاشـت وضـع تعريـف للـتخطط العمراني، ومع ذلك عرف بأنه (وضع تنظيم أو ترتيب أو تنسيق لتخصيص الأماكن بما يحقق أفضل إستخدام لها)(21)، وعليه فان التخطيط العمراني هو محاولة لتهيئة المناخ المناسب الذي يسمح للمجتمعات بايجـاد الوسائل الضرورية التي تتوفر فهيا أسباب ملائمة لحياة سكانها، أي تحقيق إطار معيشي_ـلراحة والرفاهية داخل المدن، وفي ذلك تكمن أهميـة التخطيط العمراني حيث يعمل على توظيف الإمكانات المتوفرة نحو تحقيق الإستعمال الأمثل للأرض بما يخدم المصلحة العامة. وهناك أهـداف إجتاعية بعيدة للتخطيط على الـرغز مـن أن الخطط نفسه يتصـل بالجوانب والأمساكن الطبيعية وإن الخطططات تعمد على قيم إقتصادية بعيدة ومتوسطة الأمد تؤثر بدورها على فعاليات الإنتاج والتوزيع والإنتفاع بالثروة، وضمن هذا الإطار يصبح من وظائف التخطيط الحضري تحديد إستعالات الأرض الحضرية. بحيث يؤدي كل إستعال منها دوره بأقل تكلفة وأن يؤدي كل إستعمال
نصـت الفتـرة الرابعة مـن نفس المـادة على حظـر تغيـير جنس الأراضي

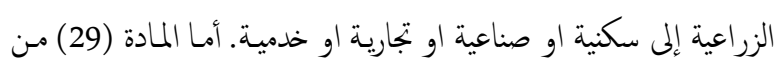
ذات القانون فقـد نصت على إنه (على كل شخص أن يلتزم بالتصاميم

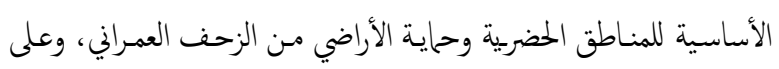
دوائر التخطيط العمراني تقديم المبررات اللازمة لإستحصال موافقة الوزارة

$$
\text { على الخرائط والتصاميم والتغييرات في جنس الأراضي). }
$$

أما المادة (33) من ذات القانون فقد نصت على إنه (يخظر على أي شخص

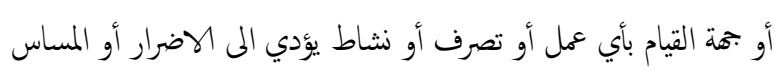
بالابعاد الطبيعية أو الجمالية أو التزاثية للمحميات الطبيعة أو الحدائق والمتنزهات العامة)، كذلك حظرت المادة (الثانية) من قانون رق (102) لسنة 1983 في شأن الخميات الطبيعية في مصر من إقامة المباني والمنشآت دون تصرئ من الجهة الإدارية المختصة كما حددت المادة

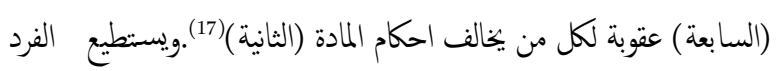
العادي رفع دعوى المسؤولية المدنية نتيجة تضررهم من البناء وإن كانت الأرض مملوكة للدولة لإن الضرر المتحقق في هذا الفعل يكون أثد وطأة على الأفراد(18).

\subsection{2 - 2.2 المطلب الثاني: ركنا الضرر والعلاقة السبية} إن مجرد النعدي على حق من الحقوق لا يثير المسؤولية المدنية مالم ينتج عنه ضرر وإن يكون هذا الضرر سببه الفعل أو التعدي الذي يشكل خرقاً لواجب لَّب قانوني، فإن قام الباني بالبناء على أرض الدولة تجاوزأكان ذلك تعدياً وفعلاً غير

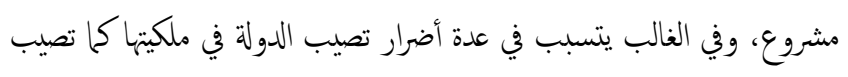
الأشخاص العادين المجاورين للبناء المتجاوز أو تصيب عامة الناس، فيكون الضرر عن البناء المتجاوز حاصلاً نتيجة واقعة البناء. وهذا ما سنتناوله في فرعين، سنخصص الفرع الأول لركن الضرر، أما الفرع الثاني فسنتناول فيه ركن العلاقة

1.2.1.2 - الفرع الأول: ركن الضرر

يعرف الضرر بأنه ((الأذى الذي يصيب الشخص في حق أو مصلحة مشروعة)(19)، والضرر ركن في غاية الأهمة لان تحقق المسؤولية يعني الحمى ليك

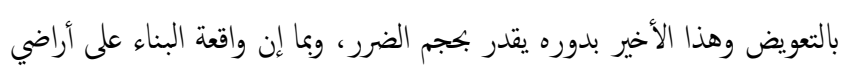




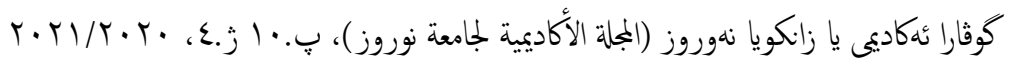

كبير على الأراضي الزراعية كما إن التجاوز أخذ نصيبه هو الآخر من هذه الاراضي وكان من الأجدر أن يراعي المشرع الكوردستاني حقيقة هذا الأمر ويتدارك هذه الأمر الذي سيؤدي إلى القضاء على الأراضي الزراعية.

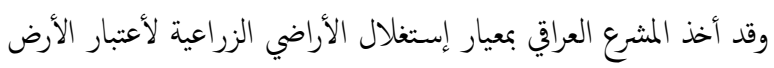

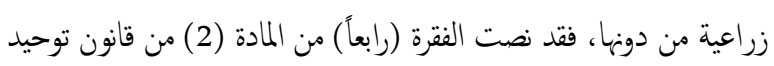
أصناف اراضي الدولة رقٌ (53) لسنة 1976 على إنه (....تعتبر أرضا زراعية لاغراض هذا القانون، الأرض التي تصلح بوضعها المادي، عند

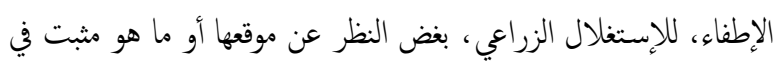
سبلها العقاري)، كما إن الفقرة (4) من المادة (31) من قانون الإستملاك العراقي رثز (12) لسنة 1981 نصت على إنه (تعبر الأرض زراعية لأغراض هذا القانون إذا كانت تستغل بالزراعة عادة أو كانت قابلة للإستغلال الزراعي بطبيعها أو بواقع حالها وقت طلب الإستملاك بصرف النظر عن مساحتها وموقعها وجنسها المثثت في السجل العقاري...(24)، فالأراضي الزراعية بهذا المعنى هي الأراضي القابلة للزراعة بحالنها أي صالحة للإنبات دون إستصلاح، ويستوي في ذلك أن تكون مزروعة بالفعل أو

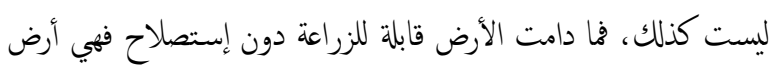

زراعية ولو لم تزرع فعلاً.

ولاشك، إن الأراضي الزراعية المملوكة للدولة تشكل ثروة هامة للبلد ومرك قوي لدفع عجلة التقدم في أغلب الدول، فالمعروف إن الأراضي في تركي

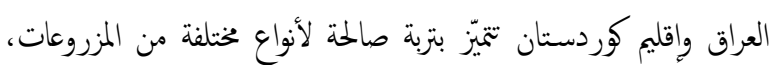
وقد حرصت العديد من القوانين والقرارات على منع التجاوز على أراضي الدولة بشكل عام والأراضي الزراعية بشكل خاص. وبالنسبة لأراضي الدولة المفوضة بالطابو للأفراد نصت المادة (1169) من القانون المدني العراقي على أن يقيم المتصرف فيها الأبنية الخاصة بالزراعة فقط، وبمغورم المخالفة فأن الابنية التي لا تكون مخصصة للزراعة فلا يجوز إقامتها على الأراضي الزراعية، وان اقاما فانها تعد ابنية مشيّدة تجاوزا على اراضي الدولة) (25).

كما بيرز تأثير البناء المتجاوز على البيئة بشكل عام وذلك من خلال تشويه ما يعرف بالصورة البصرية بسبب إنعدام المعايير الجمالية التي يجب أن تتوافر في المباني السكنية والطرق والممرات والحدائق في المدن، وبالتالي فهو نوع من انواع النلوث. ويعرف النلوث البصري بأنه (كل ما يتواجد
علاقاته الوظيفية بإيجابية، وربط أجزاء المدينة مع عالمها الخارجي بشكل متفاعل، وكذلك تطوير كل قسم من أقسام المدينة وفق مستوى معقول من نواحي الحجم والإضاءة والأماكن الخضراء في المناطق السكنية وأماكن وقوف السيارات في المناطق التجارية والتأكيد على أن نكون البيوت قوية البناء وصحية ومريحة ومبهجة بالنسبة للمناطق السكنية المختلفة لكي تنسجم والحاجات المتعددة لكل أنواع وإجحام الأسر مع الإهتام بإشكالها المتنغيرة ورغباتها المختلفة(22)، وتعيين أماكن قضاء وقت الفراغ والخدمات الأخرى التي يجتاجحا المجتع الحضري والذي يتميز بكبر ججمه وموقعه ونوعيته، إضافة إلى الإهتام بالماء المجهز وتصريف الفضلات والمنـافح الأخرى والمـدمات العامة التي يجب أن تتم بشكل فعـال وإقتصادي والأخذ بنظر الإعتبـار التطورات المستقبلية لمتغيرات المدينة وإستعلات الأرض والنمو السكاني وشوارع المدينة والخدمات العامة والبنى التحتية(23). إن ما سبق ذكهه من أهداف التخطيط العمراني يصعب تحقيقها في ظل

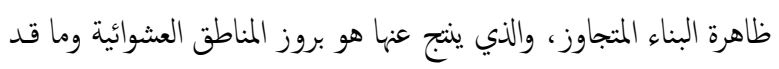
يرافق ذلك من إعتداء على جالية المدن وصعوبة توصيل الخدمات لسكان البنـاء المتجـاوز . ويــب ملاحظة إن التشرـيعات الخاصـة في التخطيط العمراني ينبغي أن تكون ذات مرونـة، بحيـث تمكن الإدارة مـن توجيـه عمليات التنمية العمرانية كما إنها لابد أن تكون متجددة وتتسم بطابع الحداثة كون الجانب العمراني في تطور دائم بفضل تطور أسـاليب الحياة وتقدم التكنولوجيا مع المحافظة بنفس الوقت على الموارد الطبيعية للدولة حيث إنها

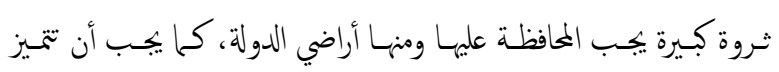
التشريعات العمرانية بالوضوعية وأن تبتعد عن الغموض والتعقيد. ثانياً: الأضرار البيئية والقضاء على الأراضي الزراعية: تُشثل الأرض الزراعية إحدى أهم عناصر الإنتاج الرئيسة في الدول، ولكن للأسف كان التوسع العمراني في العراق عامة وفي إقلم كوردستان على حساب الأراضي الزراعية، وبشكل عام فأن التوسع العمراني الحاصل في إقليم كوردستان كان من الممكن إن يتم على الأرضي التي يكن الإستفادة منها في بجال البناء لاسيا إن إقليم كوردستان يمتاز بمناطق جبلية وصخرية يمكن إستغلالها للتوسع العمراني وترك الأراضي الزراعية كما هي والإستفادة منها إقتصاديا في دف جلة التنية، لكن على العكس تماماً فإن حركة الإعار وقعت بشكل 


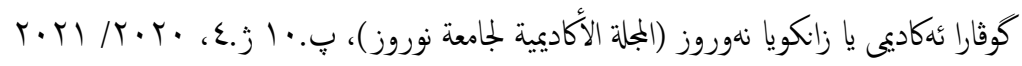

إلى رخص البناء مما يعني خخالفة قوانين البناء والأراضي الزراعية، إلا إنه لا يشترط أن تكون المساكن العشوائية مشيدة دائما بمواد البناء المتعارف عليها وهي مواد صلبة كالحديد والأججار والسمنت، وإنما يكن أن تكون مشيدة

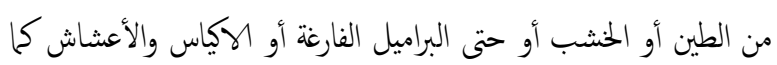
في الهند والعراق والبحرين أو أي مواد أخرى تصلح مآوى آدمية(33). وبناء على طبيعة المواد المستخدمة في تشيد المساكن العشوائية فانها معروفة بعدة تسميات في دول مختلفة فني مصر تسمى بـ (إسكان العشش) وفي المغرب معروفة بـ(السكن غير اللائق) وفي الجزائر معروفة بـ (البناء القصديري) أو (الفوضوي) أما في العراق فتدعى بـ (الحواسم) أو (التجاوز)، وتسمية التجاوز هي ذات التسمية المستخدمة في إقليم كوردستان - العراق (34). وواضح من التعاريف المذكورة إنها تركز على البناء المشيد على الأرض بأنه عشوائي وغير منظم ولا تثناول الأرض المشيد عليها البناء، فهل الأرض تعود للباني العشوائي أم هي أرض متجاوز عليها دائما بحيث تعود للغير سواء

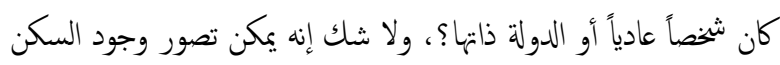
العشوائي حتى في حالة تملك الباني للأرض، ورغ ذلك يخرج البناء متواضعاً وعشوائياً فيظهر للعلن ككتل من الصفيح أو الطين أو حتى مواد صلبة ولكنها مشيّدة بطريقة غير قانونية وغير منظمة إذ على الأقل تنثقد لأجازة البناء ولا تراعي ضوابط التخطيط العمراني. ومع ذلك، فإننا نستطيع القول إن النسبة العظىى من المساكن العشوائية هي غير قانونية بناء وأرضاً، فحتى الأرض عادة ما تكون أرض متجاوز عليها كما إن الغالب أن تكون الأرض من أراضي الدولة سواء كانت داخل حدود البلديات أو خاربحا أو زراعية في أطراف المدن الكبيرة(35)، ولعل تمسية المساكن العشوائية في العراق وإقليم كوردستان- العراق بـ (السكن المتجاوز) خير دليل على ما نقول، فالسكن العشوائي هو السكن غير القانوني المقام تجاوزاً على أراضي الدولة. وعليه يمكن تعريف السكن العشوائي في العراق وإقليم كوردستان - العراق بانه عبارة عن مناطق سكنية غير نظامية مشيدة بمواد بسيطة على أراضي متجاوز عليها تعود للدولة في الغالب وتثتقر

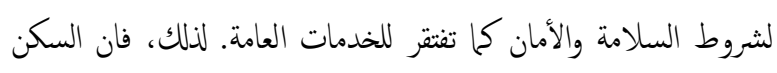
العشوائي في الغالب الأع هي مساكن مشيدة على أراضي مملوكة للدولة ولكن ليس بالضرورة أن يكون كل مسكن عشوائي بناءاً متجاوزاً على
من عناصر معحرية تؤذي الناظر عند مشاهدتها وتفقده الإحساس بالقيم الجمالية والتشكيلية، وهذه الثأثيرات ناتجة بسبب المظاهر غير الجمالية والتي لا تتلائم مع البيئة الميطة)(26). يضاف إلى ذلك إن أغلب هذه المناطق تثتقر إلى خدمات البنى التحتية وبالتحديد خدمات الصرف الصحي والماء والكهرباء وإن توافرت في بعض المناطق فأنها تكون غير نظامية وعشوائية وبالتالي تحدث مشاكل أخرى مثل إعتاد هذه المناطق على خدما المناطق الأخرى (27.). ثالثأ: الأضرار الإجتاعية: إن للبناء المتجاوز على أراضي الدولة أضرار

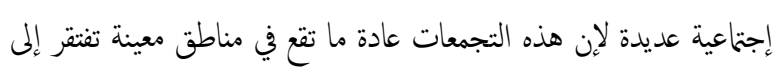
أبسط مقومات الحياة ومنها المدارس والمستشفيات، وبالتالي فأن ذلك هلك يؤدي إلى إنخاض المستوى التعليمي لهذه المناطق التي يكون مستوى

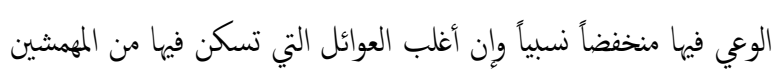
والذين لا يحرصون على تعليم أطفالم، كما إن أغلب هذه المناطق تكون

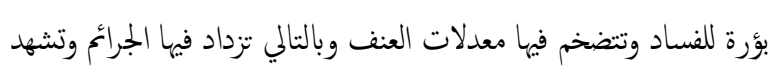
بعض هذه المناطق نوعاً من أعمال الشغب، كما تنتشر بين أفرادها الشباب ظاهرة تعاطي المخدرات وبالتالي نشوء سلوك عدواني لدى الشباب سواء فيها بنهم أو بينهم وبين ابناء المناطق المجاورة(28)، وقد تكون هذه الأماكن مرتعاً خصباً للدعارة والتجارة بالأطفال (29).

\section{رابعاً: إنتشار ظاهرة السكن العشوائي: يقصد بالسكن العشوائي أو} العشوائيات بأنه عبارة عن أبنية سكنية في مناطق داخل المدن الحضرية قائمة على على وضع اليد (الحيازة) دون توفر أي سند قانوني رسمي صادر من بحة رسمية في الدولة، فهي مناطق تنشأ بغير تخطيط عمراني ولا تتوفر فيها أي من الخدمات أو المرافق العامة أو أي مقومات البنية التحتية الأساسية، وعادة ما تشكل المساكن العشوائية مناطق فقيرة ومزدمة

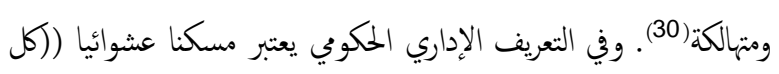

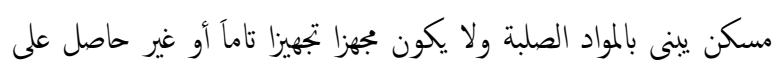
رخصة البناء، نظراً لمخالفته لقوانين تقسيم الراضي وقوانين البناء، وقوانين الحفاظ على الاراضي الزراعية)(31)، فالسكن العشوائي يفتقد إلى سند

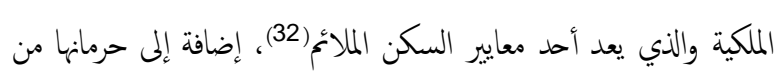
خدمات المرافق العامة كالطرق المعبدة والتعليم والصحة وغير ذلك كما تفنتقد 


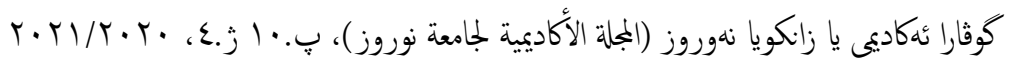

ألذى أحدث الضرر فلن يكون لهذا الأخير شأن به، ومسن هنا لزم أن يثبت مـا يسمى بعلاقة السبية بين خطأ المدعى عليه والضرير ألذى يراد جبره ، فلو أن المدعى عليه أخطأ ولكن خطأه لم يتسبب في الضررز ، أو إن الضرر لم ينشأ عن خطئه فلا مسئولية، إذل لا يعقل أن يطلب من شخص دفح تعويض عن أضرار

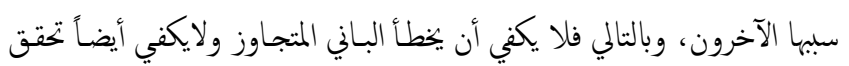
الضرر للدولة أو للغير وإنما يجب أن تكون هناك علاقة سبية بين الخطأ الذي إقترفه الباني المتجاوز وبين الضربر الذي لحق المضرور وإلا إنتفى ركن من أركان

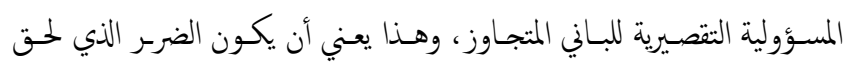

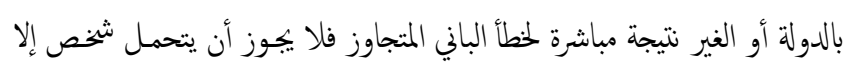

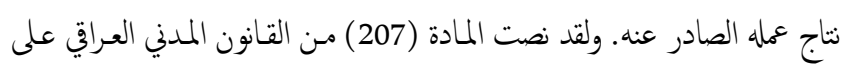
إنه (1- تقدر المحكة النعويض في جميع الاحوال بقدر مـا لحق المتضرير من ضرر وما فاته من كسب بشرط أن يكون هذا نتيجة طبيعية للعمل غير المشروع)، ويقع عبء إثبـات وجود العلاقة السببية بين الخطأ والضرر على عاتق المدعي بالتعويض، ونصـت المادة (211) مـن القانون المدني أيضاً على إنه (إذا أثبت الشخص إن الضرر قد نشأ عن سبب أجنبي...كان غير ملزم بالضمان، مالم يوجد نص أو اتفاق على غير ذلك).

\section{2 المبحث الثاني: أحكام المسؤولية المدنية عن البناء المتجاوز على أراضي الدولة} إن الغاية التي هيدف إلهيا المتضرر في دعوى المسؤولية المدنية هي حصوله على التعويض، وهذا التعويض يتخذ عدة أشكال، وان الطريق للتعويض لا يكون إلا

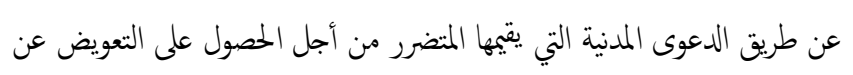
هذا الضرر الذي تسبب به الباني المتجاوز سواء كان المتضرر هي الدولة نفسها أو الغير من له مصلحة في ذلك، كما إن هناك حالات قانونية تخفف من المسؤولية المدنية للباني المتجاوز، لذلك سوف نتسم هذا المبحث على مطلبين سنتناول في المطلب الأول جبر الضرر، أما في المطلب الثاني سنتناول تخفيف المسؤولية المدنية عن البناء المتجاوز.

\subsection{2 المطلب الأول: جبر الضرر (التعويض)}

وفقاً للقواعد العامـة في المسؤولية التقصيرية، فبان المتضرـر إذا مـا أثبـت أركان المسؤولية من خطأ وضرر وعلاقة سبية، فإنه يتوجب على مرنكب الفعل الضار

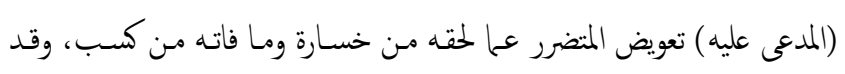
يكون النعويض عينياً وقد يكون نقدياً تقدره المحكمة، لذلك سوف نقسم هـا
أراضي الدولة، فقد يكون السبب هو عدم مقدرة الباني إقتصاديا على البناء

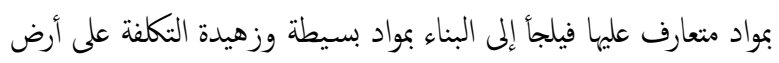
عائدة ملكيتها للباني نفه. ويشير بعض الكتاب إلى إن إنتشار العشوائيات باتت السمة الأساسية

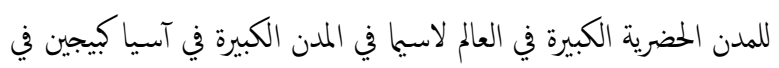
الصين ونيودلهي في الهند وبعض المدن في دول أمريكا اللاتينية كساوباولو في البرازيل وبعض المدن في دول الشرق الأوسط كالقاهرة في مصر وبعض المدن في الدول الافريقية كلاغوس في نيجيري(36)، إن إنتشار ظاهرة العشوائيات في العالم إنما تعبر في الوقت ذاته عن الفارق الطبتي الصارخ في البجمعات الحديثة، فالطبقة الساكنة في أبنية فمة هي طبقة مكتفية إقتصاديا بنيفا ساكني العشوائيات يمثلون الطبقة المعدومة التي لا حول لها ولا قوة وهذا النايز الطبقي يمثل إحد الوجوه البشعة للنظام الإقتصادي العالمي التي ترعاها منظمات دولية كصندوق النقد الدولي، فالني يتحمل مسؤولية إنتشار العشوائيات في العالم الحديث هو بالدرجة الأولى النظام الإقتادي العالي والقائين على إدارته والتنظير له (37)، وقد نتج عن هذا التايز الطبقي الحديث نظرة الطبقة المرفهة إقتصادياً وسكنياً إلى العشوائيات على إنها (خلطة من السكن البالي المتهدم، والنكدس والمرض والفقر والرذيلة)،

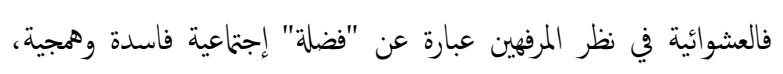
تتعفن وتتفنخ في فضاء لا إخلاقي وعنيف في الغالب(38). ولاشك، إن

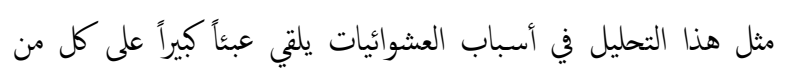

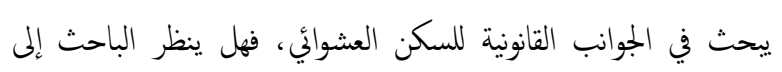
الباني العشوائي على إنه متجاوز وخارق لحزمة من القوانين المتعلقة بالملكية

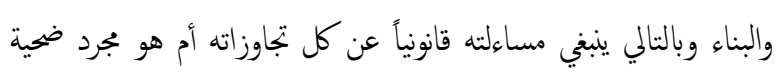
للأنظمة السياسية والإقتصادية الفاشلة داخلياً ودولياً ولتي جززت عن توفير السكن الملائم للإنسان على وجه هذه البسيطة وهو ما إضطره إلى السكن

$$
\text { في عشوائيات والبناء المتجاوز ؟!. }
$$

\subsubsection{2 - 2.2 الفرع الثاني: العلاقة السبية}

لابد في المسؤولية التصيرية من علاقة سبية بين الخطأ والضرر، وهذه العلاقة تثثل الركن الثالث للمسؤولية، ولا تقوم بدونها، فالمسئولية تهدف إلى التعويض عن الضرر الذى أحدثه المسؤول بخطئه، ومن ثخ فإن لم يكن خطأ المسئول هو 


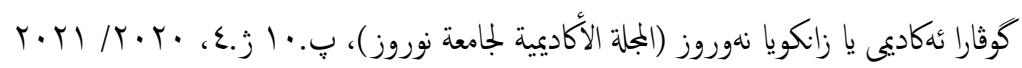

او المدينـة عوماً وحرمـانهم مـن فوائد المسـاحات الخضراء مـن خلال فقـدانهم للحديقة العامة التي كانت تبعث في نفوسهم المتعة والراحة، وللتعويض أهية كبيرة فهو الغاية الهائية من إثبات المسؤولية ويسعى إلهيا المتضرر (41).

2.1.2.2 الفرع الثاني: أوجه التعويض

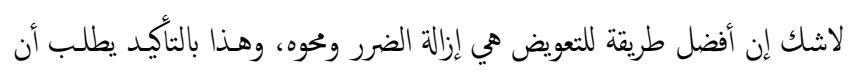
يكون الضرر قابلاً للازالة، حيث يكن آن يعود المتضرر إلى الحالة التي كان عليها قبل حدوث الضرر وهذا ما يسمى بالتعويض العيني، أما إذاكان الضرر أدبياً أو ماساً بجسد الإنسان فن المستحيل إعادة الحال إلى ماكان عليه قبل وقوع الضركر وبالتالي فإننا ننتجيء إلى النعويص بمقابل. وفيما يتعلق بالضركر الذي يلحق بالمالك و الغير جراء البناء المتجاوز فيمكن أن يتم تعويضه تعويضاً عينيـ(42)، حيث ترفع دعوى التعويض من قبل المضرور نفسه إذا كان كامل الأهلية وإلا رفعت من قبل من ينوبه كما يمكن للشخص المعنوي الخاص كالشركات والنقابات المهنية والمجميات والمؤسسات والشخص المعنوي العام كلالدولة أن يرفع دعوى التعويض مـن خلال مثثلها القانوني. وسوف نتناول كل وجه من أوجه التعويض على النحو يأتي:-

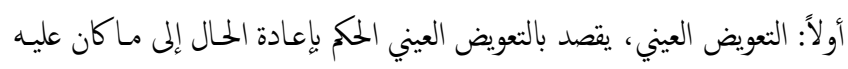
قبل إن يرنكب المسؤول الخطأ الذي أدى إلى وقوع الضرعر (43)، ويعتبر التعويض العيني متى مـاكان مككناً مـن أفضل طرق التعويض لإنه يقوم بإعادة الحالة إلى لى ماكان عليه قبل وقوع الفعل الضار، وقد نصت المادة (209) من القانون المدني العراقي على إنه (... يجوز للمحكمة تبعاً للظروف وبناء على طلب المتضرر أن تأمر

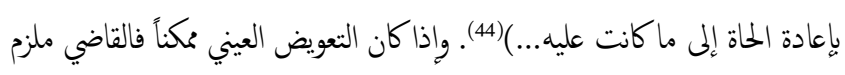
بالمكى به إذا ما طلبه الدائن أو تقدم به المدين، وبكل الأحوال فيان هذا التعويض لا يمكن تصوره إلا في الخطأ الذي يكن إزالته. وتأسيساً على ذلك فأن المتضرر من البنـاء المتجاوز يحق له المطالبة بإزالة البناء المتجاوز على أراضي الدولة حتى وإن لم تقم الدولة بإزالته مباشرة مادام إزالة البناء مككناً ويكن بالتالي إعادة الحال إلى ماكان عليه(45). ثانياً: التعويض بمقابل، قد يكون التعويض بمقابل نقدياً وقد يكن غير نقدياً ومثال الأخير هو التعويض الذي يتمثل في نشر - الحكى الصادر بإدانة المتهم في جرائم السب والقذف في الصحف، أمـا الأصل في التعويض عن الضربر في المسؤولية التقصيرية فهو النعويض النقدي وقد نصت الفقرة الثانية من المادة (209) من القانون المدني العراقي على إنه (ويقدر التعويض بالنقد...)، وذلك لما تملكه النقود من وظيفة لإصلاح الضربر الذي ينتج عن الفعل غير المشروع، كما يتميز هذا
المطلب على ثلاثة فروع سنتناول في الفرع الأول تعريف التعويض أما الفرع الثاني سنتناول أوجه التعويض أما الفرع الثالث فسوف نخصصه لتقدير النعويض.

\subsubsection{2 - 1الفرع الأول: تعريف التعويض}

يعرف التعويض في نطاق المسؤولية المدنية بأنه ((مبلغ من النقود أو أية ترضية من جنس الضرر تعادل ما لحق المضرور مـن خسارة وما فاته من كسب كانا نتيجة طبيعية للفعل الضار ))(39)، والنتويض هو أثر لقيام المسؤولية المدنية سواءكانت عقدية أم تقصيرية، ويتم المطالبة بالتعويض عن طريق دعوى التعويض بعد توافر أركان المسؤولية، وهـذه الدعوى هي الوسـيلة القضائية التي مـن خلالها بتمكن المضرور من الحصول على النعويض عن الضربر الذي لحق به جراء الفعل الذي إرتكبه المدعى عليه، فالتعويض أداة لجبر الضربر عندما لا يكون التنفيذ العيني مككناً، فهو أداة للثفيذ بمقابل أو التنفيذ بطريق النعويض (40). وبالنسبة لفعل البناء المتجاوز على أراضي الدولة، فإنه يتصـور أن تقوم الدولة كمدعي بالضرمر برفع دعوى التعويض ولا يوجد هناك من مانع قانوني من ذلك بإعتبار إن الدولة مالكة للأرض التي تم التجاوز عليها بالبناء ودون إذهـا مـ قبل الباني، ولكن الدولة في أغلب الأحيان لا تقوم بالإلتجاء إلى هذه الدعوى لكونها تمتلك وسائل تنفيذية أخرى مباشرة تعطيها الحق بإتخاذ إجراءات وقائية وعلاجية كنها تتمتع بالسيادة على اراضيها، ولكن من الممكن أن يطالب الغير من الأشخاص الطبيعيين أو المعنويين بالتعويض عن الأضرار التي أصاتهم جراء البنـاء المتجاوز على أراضي الدولة، فقد يقوم شخص بالبناء على أرض الدولة التي هي خخصصة لحديقة عامة ويتضرر منها أصحاب الدور التي تقابل هذه الحديقة ويمنعهم من الإستفادة من تلك الحديقة العامة حيث إن الملاك المجاورين يكون لهم حق إرتفاق بعدم البناء في تلك الأرض ويكون ذلك الإرتفاق داخلاً ضمن أثمان عقاراتهم، فإذا مـا تم البناء يكون الملاك المجاورين قد خسروا جزءاً من أثمان عقاراتهم إضافة إلى خسارة ميزات التخطيط العمراني، أو قد يشيد شخص بناء على أرصفة الطريق العام والذي تعود ملكينه للبلديات مما يعيق حركة المرور لدى المارة فيستبب بوقوع إصابات لمم أو لغيرهم، أو قد يفوت الفرصة للأشخاص العادين في ريح ححقق في المستقبل، ومن أمثلة ذلك الشخص الذي يشتري قطعة أرض تقابلها حديقة عامـة من أجل المضاربة عليها في المستقبل ومن ثم يأتي المتجاوز ويقوم بالبناء على تلك لك الحديقة مما يتسبب في إنخفاض قيمة الأرض، كما قد يتصور أن يكون الضرحر معنوياً من خلال فقدان أصحاب الدور السكنية للجالية المطلوبة في الحي السكني 


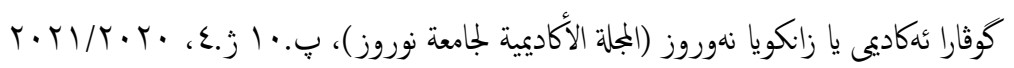

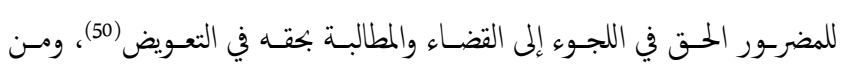
البديهي إن دعوى النعويض عن الفعل غير المشروع هي دعوى مدنية وفي أغلب الأحيان فأن الفعل الغير المشروع ينطوي على فعل يعاقب عليه جنائيـاً وبالتـالي فلا يجق للمضرور رفح دعوى التعويض التي هي دعوى مدنية قبل نهاية الدعوى

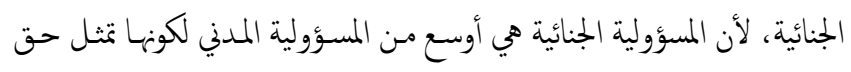

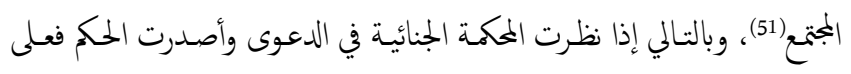
المحكة المدنية أن تأخذ هذا الحكم بعين الإعتبار مـن حيث ثبوت الوقائع وهذا مـا أكدت عليه نص المادة (107) من قانون الإثبات رخ (107) لسنة 1979 بقولها (لا يرتبط القاضي المدني بالحكي الجزائي إلا في الوقائع التي فصل فيها هذا الحكي ليكي وكان فصله فيها ضرورياً). إن الهدف النهائي من المسؤولية التقصرية كما ذكرنا هو جبر الضركر وإعادة وضع المضرور إلى ماكان عليه قبل وقوع الضرري، وهذا الهدف يسانده ويدعمه مبدأ يسيطر على تقدير التعويض في أغلب القوانين المدنية وهو مبدأ التعويض الكمل

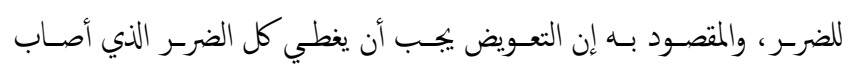

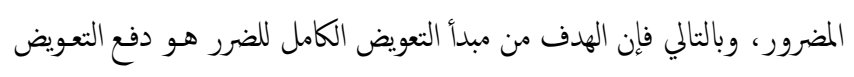
إلى المضرور بشكل معادل لمقدار الضرر من دون أن يثأثر مقدار التعويض وججمه

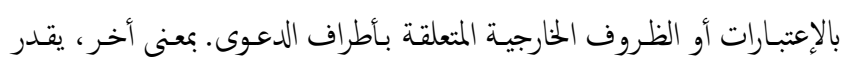
التعويض تقديراً موضوعياً تكون العبرة فيه بمدى الضرر فقط دون أي ظرف آخر وخاصة ما يتعلق بالمسؤول، وبالتـالي لا تكون لدرجة جسامة خطأ هـا الأخير ولا لظروفه الخاصـة (كركزه وحالتـه الماليـة والإجتاعيـة) أي تـأثير في تقــير

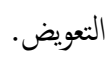
ولكننا نجد إن ما يخفق من حدة المبدأ المذكور أعلاه هو مبدأ السلطة التقديرية

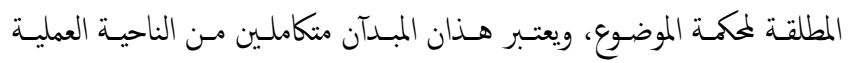
والنظرية، وبالرغز من تباين المواقف الفقهية والقضائية بشأن مراعات جسامة الخطأ والحالة المالية للمسؤول والمضرور (52)، إلا إنـا ؤيد الرأي الذي يأخذ بهذه العوامل بعين الإعتبـار في تقدير التعويض لأن المسؤول عن البنـاء المتجاوز كما ذكرنا قد يكون مضطراً إلى التجاوز بالبنـاء على أراضي الدولة لحاجته الماسـة والضرورية لإيواء عائلته فلا بـد أن يستجيب القاضي عند تقديره للتعويض المستحق عليه مقابل الضرر الذي سببه للمضرور حالة هذا المتجاوز المالية ومدى جسامة خطئه(53)، لما يملكه القاضي من سلطة تقديرية في هذا الخصوص وتختيقاً للعدالة المنشـودة من دون أن يصرحح بذلك في الحكى وهذه هي الأسباب التي
التعويض بسهولة تنفيذه وتلجأ إليه المحكة في حالة عدم تمكنها من الحكي بالتعويض العيني (46)، وبالتالي فيمكن للمحكمة، عند تعذر النعويض العيني والمتمثل في إزالة التجاوز ، أن تحكم للمتضرر بالتعويض النقدي عن مـا أصابه مـن ضرر حقيقي

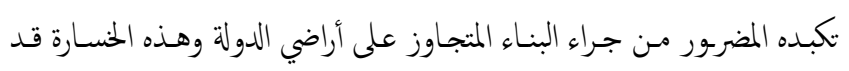
تتمثل في هبوط أسعار القطع السكنية بعد شروع المتجاوز بالبناء عليها، وبالنسبة للدولة فان الحسارة تتمثل في فوات المنغعة من الارض خلال مدة التجاوز (47).كما يشمل التعويض فوات الفرصة، فلا يككن للمتويض العيني أن يجبر هذا النوع من

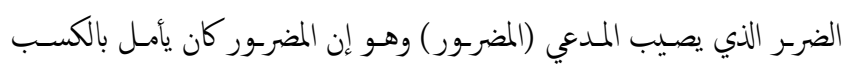
الفائت وكان هذا الأمل مبني على أسباب معقولة وجدية أي إنه كان يمتلك فرصة مثل الشخص الذي كان ينوي بيع داره قبل أن يأتي المتجاوز ويبني بـأرض الدولة ومما أدى إلى خفض سعر الدار بشكل كبير لعدم رغبة الناس بشراء دار تجاوره مناطق متجاوزة.

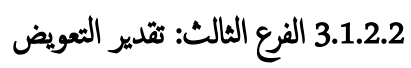

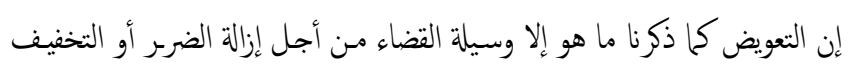
من وقعته على المضرور ، وهو بالتالي ليس عقوبة للمسؤول، كما يجب ألا يكون التعويض مصدراً لإثراء المضرور، وبهذا المفوم يتدخل القاضي في مسألة التعويض

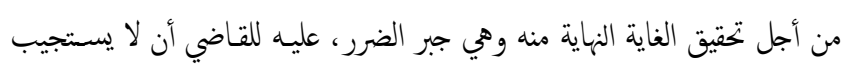

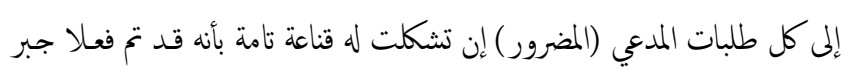
الضرر أو التخفيف منه من خلال التعويض الذي أقره المتضرر. وعادة، يقدر النعويض في المسؤولية المدنية التقصيرية حسب الضرر الذي لحق بالمتضرر، وهو ما نصت عليه المادة (207) من القانون المدني العراقي التي جاء فيها (1- تقدر

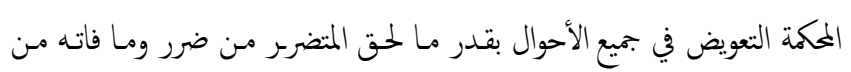
كسب بشرط أن يكون هذا نتيجة طبيعية للعمل غير المشروع .2- يدخل في

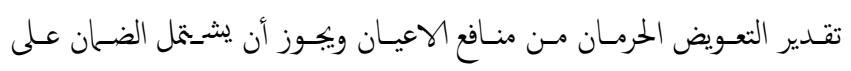
الأجر )(48). ويفهم من هذا النص إن النعويض يرتبط وجودأ وعدماً مع الضركر فلا يككن للمدعي أن يطالب بالتعويض إلا إذا أثبت وجود ضرر لحق به أو بمن ينوبه، ويتعين على المدعي إثبات ذلك تطبيقا لقاعدة البينة على من إدعى والميمن على من انكر وجدير بالذكر إن الحكم النهائي الذي يصدر بتعويض المضرور هو حكم كاثف لحقه

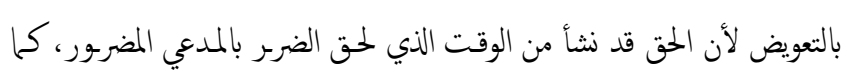
يكفي أيضاً أن يكون الضركر في المستقبل أمراً معققاً، ومنذ تلك اللحظة ينشأ. 


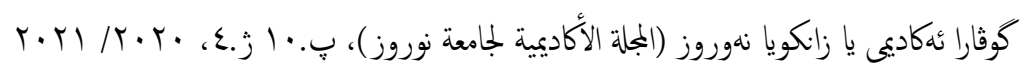

سببه لا يكون ملزماً إلا بتعويض الذي تراه المحكة مناسباً). وعلى هذا فإن حالة الضرورة هي حالة طارئة يصيب الإنسان من الحرج والمشقة ييلخ حداً إن لم يتقدم

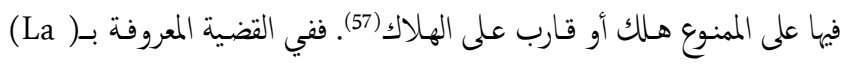
femme Menard الأوساط الحقوقية، قامت المرأة بسرقة كمة من الخبز ليلاً من فرن مُجاور لمنزلها تكفي لإعالة أولادهـا الذيـن نال منهم الجموع، وقبض عليهـا لكن أحـد القضاة المغورين الشهرة آنذاك المدعو (ماجن أند) اصدر حكماً يقضي براءة المدعى عليها مما أسند إيها، وقد أثارت هذه القضية عاصفة من العطف الشعبي على القاضي الذي لقب بالقاضي الطيـب. وقد صدق هذا القرار إستـنئافاً مـن قبـل المحكمة العليا(58)، فحلة الضرورة حالة ارتبطت بوجود الإنسان، وقد أخذت بها مُختلف التشريعات الحديثة، ولها أهية بالغة في كل أطوار الحياة الإنسانية ولها قيمها كمالة

وجدت لتبرير مواقف حدثت إضطراراً كالباني المتجاوز المضطر.

ولقيام حالة الضرورة يجب أن تتوافر شروط معينة وهي على النحو الآتي:أ. أن يكون الشخص مهدداً بخطر حال بهدد النفس أو المال، ونسطيع القول إن الباني المتجاوز المضطر مهدد بخطر لا بهدده شخصيا وانما جميع افراد عائلنه، فهذا المتجاوز قد يجد نفسه بلا مأوى أو سكن يحمي نفسه وعائلته من التشرد، واذا كان صحيحا ان الخطر الناجت عن انعدام المأوى لا يصيب

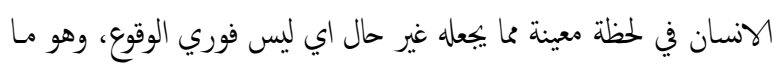
يعـني في النهايـة انعـدام شرط حـالة الضركورة لتخفيـف مسؤولية البـاني المتجاوز اضطرارا، ولكن دعونا نتصور رب عائلة معدم القدرة المالية بحيث لا يككنه شراء مسكن ولا استئجاره ولم يتلقى مساعدة في هذا الشأن من اي شخص او جهة حكومية ولا يتتقد انه سيتلقى تلك المساعدة، لا شكك وسك ان غريزة رب الاسرة وواجبه الاخلاقي، في المحافظة على عائلنه واطفاله من برد الشتاء القارص وحر الصيف اللاهـب، ستـدفعه الى انشـاء بناء

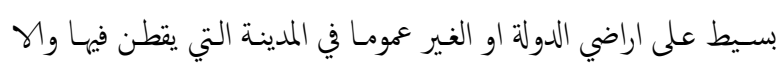
كان مصير العائلة والاطفال الهلاك لا محالة، ويجـب على القاضي ان لا يقف عند حرفية النصوص وانما ان يتحرى العدالة التي يمكن استشعارها من روح النص، وهذا القول ليس فيه تشجيعا على التجاوز بالبناء على اراضي الدولة بقدر ما فيه دعوة للقضاء من اجل التمييز بين حالات التجاوز

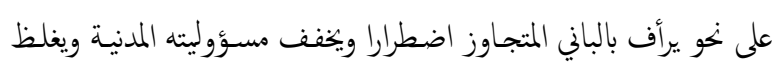
في محاسبة من لم يكن مضطرا في تجاوزه، ويجب ان لانسىـ ان الانسان
دفعتنا إلى التمييز بين المتجاوز المضطر وغير المضطر. فلا يعقل أن يضيف القاضي عبئًا مالياً ثقيلاً على المتجاوز الذي قام بتشيبد بنـاء متواضع مؤقتاً ليجنب نفسه وعائلته مـن حرارة الصيف وبـرد الثـتاء والتشرحد والضياع والنوم في الأزقـة والشواع وخصوصاً إن الأرض التي تم البناء عليها هي مـلك للدولة، وبالتـالي فأن قياس نسبة هذا الضرر يكون قليلاً بالنسبة للحاجة الماسة التي تحقتت بهذا التجاوز، بعكس المتجاوز الغير المضطر الذي يتخذ من تجاوزه على أراض الدولة مجرد الرفاهية ومن دون أن يكون في حاجة ماسة إلى ذلك التجاوز مستغلاً نفوذه وسلطته في سبيل تحقيق مكاسـب أكثر على حسـاب الدولة والأفراد، فهذا المتجاوز لابد أن يتم أخذ وضعه المالي بعين الإعتبار ومدى حاجته إلى التجاوز وإستغلال أراضي الدولة ومع تعويض الأفراد عن الضربر الذي لحق بهم مـن جراء تجاوزه إن وجد هناك ضرر.

\subsection{2 المطلب الثاني: تخفيف المسوولية المدنية عن البناء المتجاوز}

إن الخطأ كما ذكرنا سابقاً، يتكون من عنصر مادي المتمثل بنعل النعدي والعنصر المعنوي المتمثل بالإدراك أو التمييز وبالرغ من توافرها أحيانا إلا إن هناك حالات لا يعتبر توافرها في الفعل خطأ، وهذه الحالات نص عليها القانون المدني العراقي في المواد من (212- 215) وهي حالة الدفاع الشرعي وهالة تنفيذ أوامر رئس تجب طاعته وهالة الضرورة، ولكننا نجد إن المتجاوز بالبناء على اراضي الدولة لا يكنه اللجوء لحالة الدفاع الشرعي لنني خطئه لإن حالة الدفاع الشرعي تتطلب أن يكون هناك خطر هال على نفس الشخص أو على نفس غيره والخطر بجد ذاته صادر عن المضرور نضسه وهذا ما لا يكنن تطبيقه على المتجاوز (54)، وإن كان نص المادة (41) من قانون العقوبات العراقي رقة (111) لسنة 1969(55) ينص على إنه (لا جريمة إذا وقع الفعل إستعالاً لحق مقرر بمقتضى القانون...) كذلك المواد (41-46) فهي كلها تنص على جرائم ولايكننا تطبيق حالة الدفاع الشرعي بأي شكل من الأشكال ، كما لا يكننا آن نتصور أن يتسمك المتجاوز بتفيذ أوامر رئس تجب طاعته لأن من الصعب أن يثبت إنه كان يعتقد بمشروعية الفعل

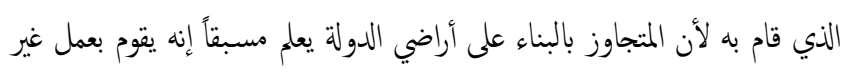
مشروع(56) وتبقى حالة الضرورة هي الأقرب إلى تخنيف مسؤولية المتجاوز. فقد نصت المادة (213) من القانون المدني العراقي على إنه (1- يختار أهون

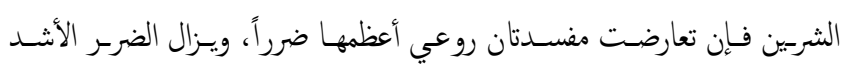

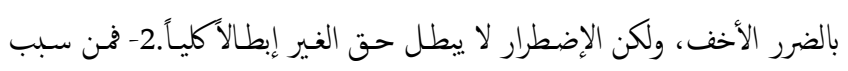

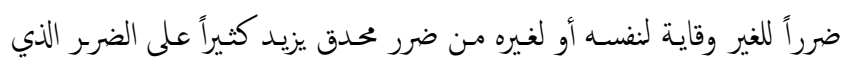




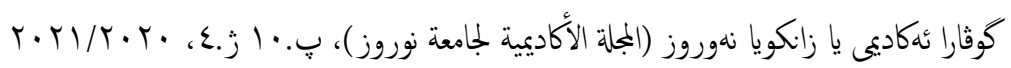

صدر مؤخرا في اقليم وزردستان العراق وهو قانون تمليك الأراضي المتجاوز عليها ضمن حدود البلديات في إقليم كوردستان - العراق رق (3) لسنة 2019. ونخن من جانبنا لا ؤيد تمليك الراضي المتجاوز عليها للبناة ولا لغيرهم، لان في ذلك تشجيعا على التجاوز كما يشهد بذلك الواقع، ولكن ان

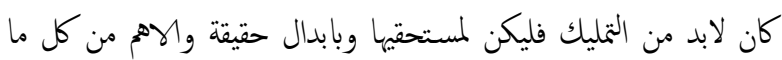
ذكر هو تطوير وتحسين تلك العشوائيات من ناحية البنى التحتية والخدمات بعد صدور قانون او قرار التمليك.

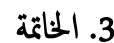
بعـد الإنتهـاء مـن كتابـة هــا البحـث المتواضع، فإنــا توصـلنا إلى جمـلة مـن الإستنتاجات والتوصيات لعل أهمها ما يأتي:

1.3 الإستنتاجات

إذا كانت الدولة تكنفي في الغالب بالأسـاليب القانونية الإدارية في التعامل مع الباني المتجاوز، فإن الغير (الشخص العادي) المتضرر من البناء المتجاوز له رفع دعوى المسؤولية المدنية على البـاني المتجاوز متى مـا توافرت أركان

$$
\text { هذه المسؤولية. }
$$

ان ركن الخطأ في المسؤولية المدنية عن البناء المتجاوز فإنه يتمثل في النعدي وخخالفة نظام إجازة البناء وضوابط التخطيط العمراني التي يراعي فيها عادة المصلحة العامة للمواطنين إضافة إلى التعدي على حقوق عينية خاصة بالغير كما في حقوق الإرتفاق بعدم البناء في أراضي الدولة المجاورة لملكية الغير. ينتجج عن البنـاء المتجـاوز على أراضي الدولة أضرار عـدة، فإضـافة إلى الإعتداء على ملكية الدولة للأرض، يقع الضرر على الأشخاص العاديين وهذه الأضرار نتيجة مخالفة قوانين التخطيط العمراني والبلديات وكذلك تشويه الأراضي الزراعية والأضرار بالبيئة والقضاء على المساحات الخضراء بجانب الأضرار الإجتاعية التي يسبها ظهور مناطق عشوائية تثتقد إلى

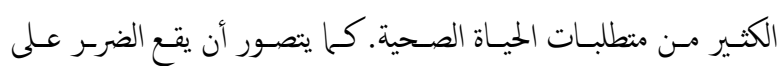
الأشخاص الطبيعين والمعنويين على حد سواء من جراء البناء المتجاوز. لكل متضرر رفع دعوى المسؤولية التصيرية على الباني المتجاوز - وهـا أطراف دعوى المسؤولية عن البناء المتجاوز - حسب القواعد العامة متى مـا توافرت أركان هذه الدعوى من خطأ وسبب وعلاقة سبية.
الذي لم يستطع الحصول على مـأوى لعائلته في المكلن الذي يعيش فيه انما هو ضحية من ضحايا فشل الدولة وحكوماتها المتعاقبة.

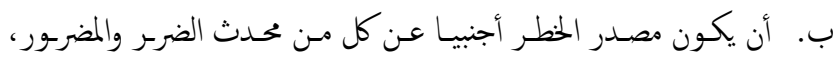
فالباني المضطر هو الذي لا يملك سكناً لإيواء نفسه أو عائلته وهذا الخطر الذي مهدده ليس بسببه أو بسبب المضرور من البناء على أراضي الدولة إنـا مصدره أجنبي أياًكان فقد يجد الباني المتجاوز انه غير قادر على إيجاد سكن بسب وضعه الإقتصادي مما يضطره إلى اللجوء إلى أراضي الدولة من أجل ان يوفر لنفسه سكناً متواضعاً.

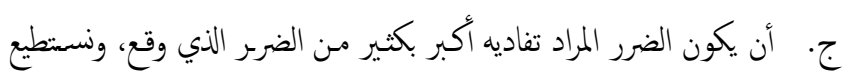
أن نقـول إن الضرـر الذي يتسـبه البـاني المضطر للدولة أو الأشـخاص

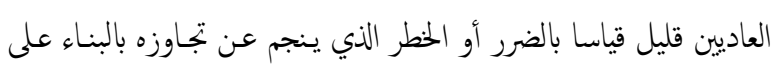

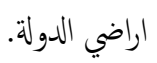

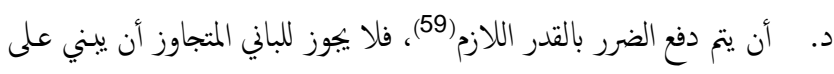

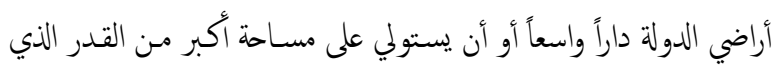
يكنه مـن إيواء نفسه ومن يعيلهم. لذلك إذا كان البناء على أراضي الدولة إضطراراً نكون أمام حالة الضرورة التي تخفف مسن المسؤولية المدنية للبـاني المتجاوز إذا توافرت فيه الشروط المتقدمة لاسيا أن ذلك لا يمنع من إبطال حق الغير فهو ملزم بالتعويض الذي يجده القاضي مناسباً عن الضربر الذي تسبه للغير. هـ. وبقدر تعلق الامر بصير البناء المتجاوز على اراضي الدولة، فيلاحظ ان القوانين العراقية والكوردستانية اضافة الى مسلك الحكومات العراقية المتعاقبة وكذلك الحكومات في اقليم كوردستان -اعراق انها دأبت على البت في مصير البناء المتجاوز على نحين اثنين لا ثالث لما، النحو الوول هو ازالة البناء المتجاوز وفقا للاجراءات المنصوص عليها في القوانين والقرارات الخاصة بازالة البناء المتجاوز كما في قانون اقليم كوردستان العراق رق (3) لسنة 2018 بشأن منع وإزالة التجاوز على أراضي الدولة. اما النحو الثاني من البت في مصير البناء المتجاوز فهو تمليك الارض المتجاوز عليها مع

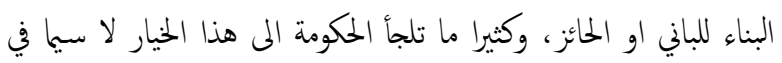
حالة استفحال ظاهرة البناء المتجاوز وتشكل احياء سكنية عشوائية مترامية الاطراف في اطراف المدن الكبيرة، وعادة ما يتم التمليك بابدال رمزية يراعي فيها المقدرة المالية للمتجاوزين كما هو الحال في القانون الذي 


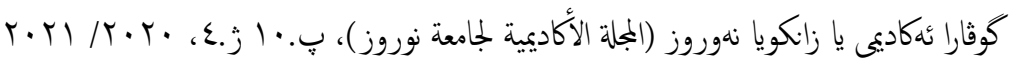

إيصال مختلف الخدمات الأساسـية إليها كالشوارع والماء والكهرباء وبقيـة الخدمات الصحية والتعليمية والتزفيية وغيرها، لأن مجرد تمليك أراضي الدولة المتجاوزين لا يوفر لهم حقهم الدستوري في السكن الملائم دون إعـادة تأهيل تالك الأبنية والأحياء وإيصال الخدمات.

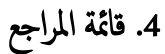

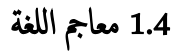
1. 2.

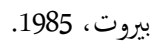

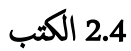

1. أشرف ابو العيون عبدالرحيم، النلوث البصري واثره على المدينة المصرية المعاصرة، مؤتر

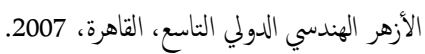
2. . د. أنور سلطان، الموجز في النظرية العامة للالتزام، دار النهضة العربية، بيروت، 1983.

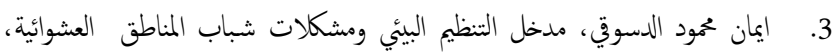
دارالوفاء، الوسكندرية، 2016. 4. بنيامين يوخنا دانيال، التجاوزات على الوراضي المملوكة للدولة أو البلديات ونطاق سريان القانون رقة (114) لسنة 1963 المعدل، أربيل، 2001.

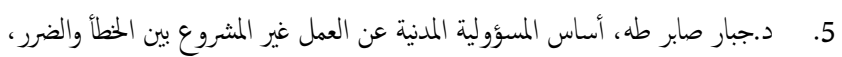

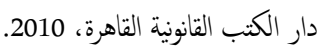

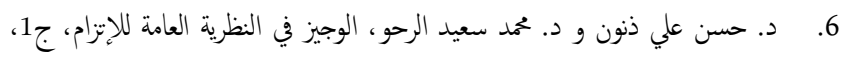

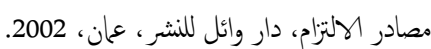
7. د.حسن طالب، المدينة والجريمة، الأحياء الفوضوية في النسيج العمراني الحضري

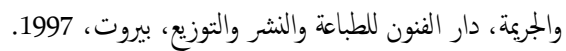

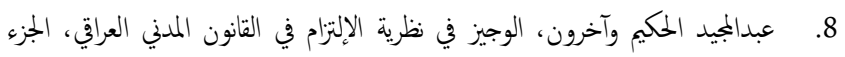

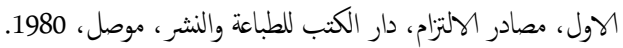

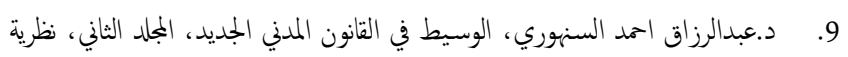

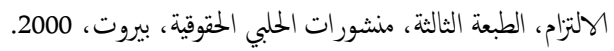

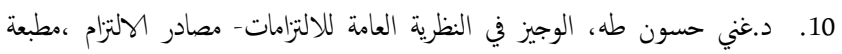
المعارف، بغداد، 1971. 11. د.سعدون العامري، التعويض عن الضرر في المسؤولية الثقصرية، مركز البحوث

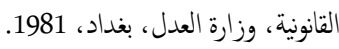
12. د.سليان مرقس، الوافي في شرح القانون المدني، الاتزامات، ج2، الجماد الثاني، بدون مكان نشر، 1988. 13. مايك ديفيز، كوكب العشوائيات، ترجمة ريبع وهبة، المركز القوي للتزجمة، القاهرة، .2013 14. محم فاضل يوسف، دور الشرطة في موابحة مشاكل المناطق العشوائية، دار النهة

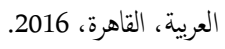
15. د.مصطفى مرعي، المسؤولية المدنية في القانون المصري، الطبعة الثانية، مطبعة الاعتماد، المرية

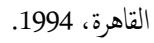
16. د.منذر الفضل، النظرية العامة للالتزامات، الجزء الأول، دار الثقافة للنشر والتوزيع، عهان، ان 1996.
يككن للباني المضطر الإستفادة من حالة الضرورة حين مسألثه مدنياً بإعتبار إن البـاني في تجاوزه إضطراراً على أراضي الدولة إختار أهون الضركرين، الضرر الأول هو بقاء الباني وعائلته في العراء دون سكينة ومأوى وتحمل حرارة الصيف وبرد الشتاء وهذا الضرر الأشد، والضرر الثاني هو التجاوز على أراضي الدولة بالبناء بإستعمال مواد بسيطة وفيه مـا فيه مـ أضرار. وبخصوص شرط فورية الخطر (الخطر الحال) اللازم لتطبيق حالة الضرورة فاننا ندعو القضاء المى الاجتهاد في هذا الشأن وعدم الوقوف على حرفية النصـوص، فـالخطر الذي يبـيح تخفيـف المسؤولية مـن منظـور العـدالة والانصاف هو الخطر المحدق بالشخص سواء وقع في الحال او تراخى مدة من الزمن، ولا شك ان منعدم المأوى محاط هو وعائلته بخطر الهلاك بردا

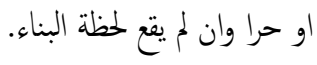

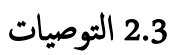

نهيـبـ بالحكومـة العراقيـة وحكومـة إقلـيم كوردسـتان العمل على تعزيـز الإستثار في قطاع السكن وتهيئة الظروف التي تساعد على إمتلاككل مواطن لوحدة سكنية بحيث لا ييقى في حاجة للتجاوز على أرض الدولة بالبنـاء لاغراض السكن، وهو مـا يعـد في النهاية تنفيذاً لإلتزام دسـتوري يفرض على الحكومة توفير السكن الملائم لكل شرائح المجتمع. نوصي الحكومة بالعمل على بناء وحدات سكنية عمودية للمتجاوزين الذين يفتقدون لوحدة سكنية على وجه الإنستقلال وتمليكها لهم بسعر تكلفـة البناء، على أن لا تتم إزالة الأبنية المتجاوزة إلا بعد إنتهاء الوحدات السكنية

$$
\text { وإسكان المتجاوزين مع عوائلهم فهيا. }
$$

نوصي المثرع العراقي والكوردستاني بالتميـيز في المعاملة القانونية بين الباني

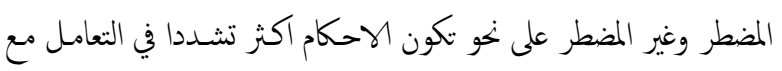
الباني غير المضطر. نوصي القضاء العراقي بمراعاة حالة الاضطرار للباني عند اثارة مسؤوليته المدنية عن البناء المتجاوز على نخو تكون مسؤوليته المدنية مخفقة امـام الدولة والغير. نوصي الجهات الحكومية بالعمل على إعادة تأهيل الأحياء السكنية المتجاوزة (العشوائية) التي صدرت قوانين أو قرارات بتمليكها للمتجاوزين من خلال 


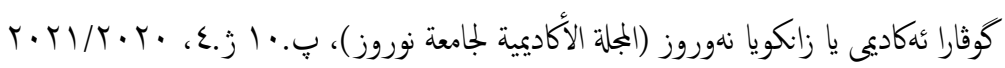

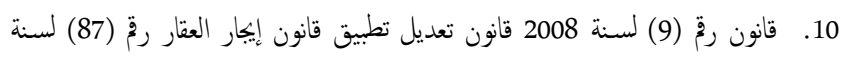
(1979 المعدل.

11. قانون حاية وتسين البيئة العراقي رقٌ (27) لسنة 2009.

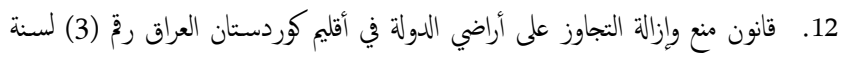

2018

13. اللائحة التنفيذية لقانون البناء المصري رمّ 119 لسنة 2008.

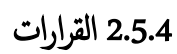

1. قرارجلس قيادة الثورة المنحل رق (154) لسنة 2001.

\section{4}

1. وليد عبدالسلام فريوان و عبدالسلام محمد الرشيدي، تداعيات البناء العشوائي

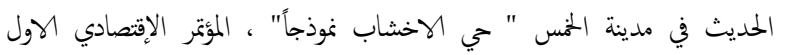

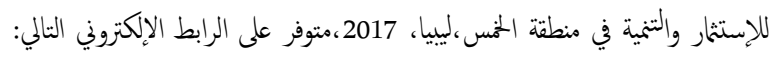
http://ecidiko.elmergib.edu.ly/papers/ECIDI KO2017-022\%20P\%20.pdf 2. السكن العشوائي يساعد على انتشار الامراض والجريمة، تقرير منشور في الانتزنت على التالي:

https://annabaa.org/arabic/rights/21027

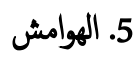

1.

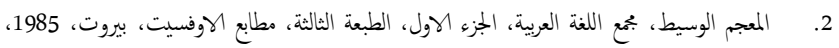
3. نظام الطرق والأبنية العراقي رق (44) لسنة 1935، المنشور في جريدة الوقائع العراقية العدد (1465)،

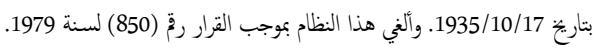

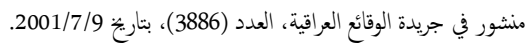

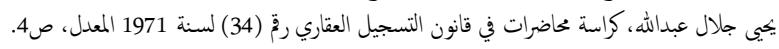

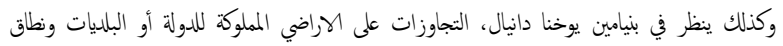

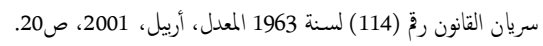
وليد عبدالله مظاهر، التعدي الحضري في مدينة الكويت، مجلة دراسات الخليج والجزية المبرة العربية،

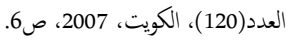

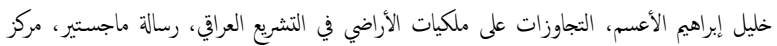

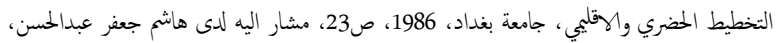

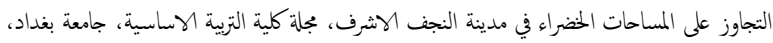

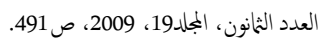

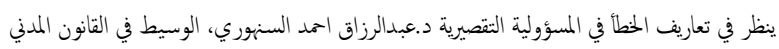

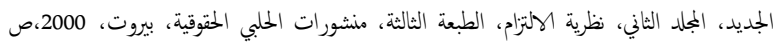
.882-879

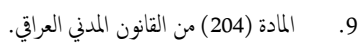

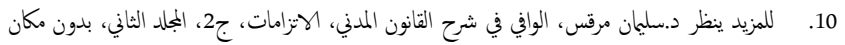

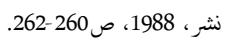
11. للمزيد ينظر د. حسن علي ذنون و و د. محمد سعيد الرحو، الوجيز في النظرية العامة للإتزام، ج1، مصادر

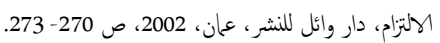

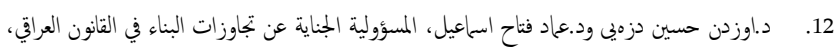

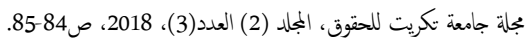

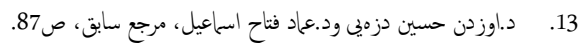

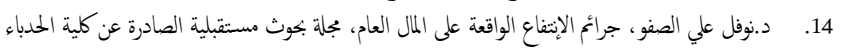

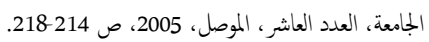

17. ييى جلال عبدالله، كراسة محاضرات في قانون التسجيل العقاري رقٌ (34) لسنة 1971 المعدل.

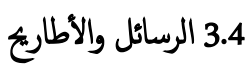

1. حسيب صاح اساعيل، البناء غير القانوني على الأراضي الزراعية، رسالة ماجستير

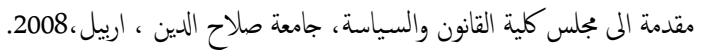

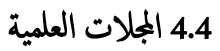

1. د.اسراء موفق رجب، التلوث البصري في مدينة بغداد "السكن العشوائي في حي

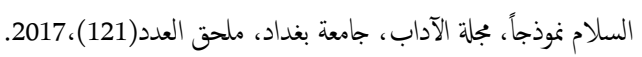

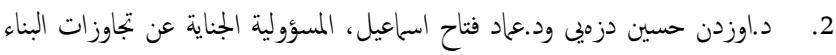

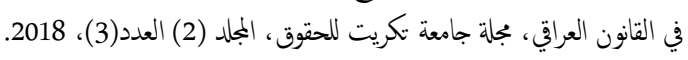

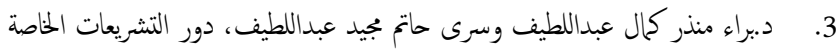

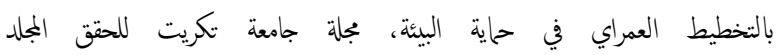

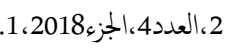

4. د.بيرك فارس حسين وم.م منار عبدالمحسن عبدالغني، التعويض والغرامة وطبيعتها

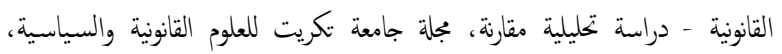

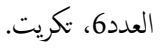
5. د.جال باقر مطلق وحيدر رزاق محمد الشبر، تحديد مقترحات لحل مشكلة السكن

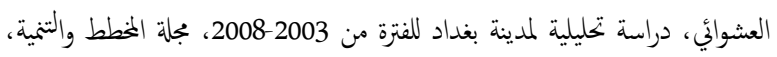
العدد (33)، الصادرة عن مركز التخطيط الهقيلي والحضري، جامعة بغداد، 2016.

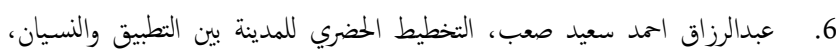
بحث منشور في مجلة دراسات تربوية، المجلد(2)، العدد(7)، مركزالبحوث والدراسات التزبوية، وزراة التربية، بغداد، 2009. 7. د.فرهاد سعيد سعدي و د.عبدالله فاضل حامد، الجوانب المدنية والتجارية للحق في

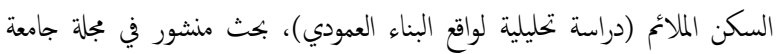
نوروز ، العدد (8)، 2016.

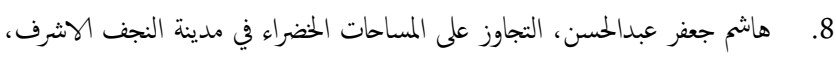

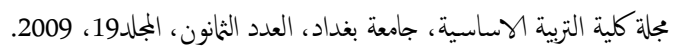
9. وليد عبداله مظاهر، التعدي الخضري في مدينة الكويت، مجلة دراسات الخليج

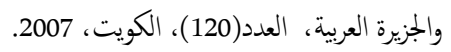

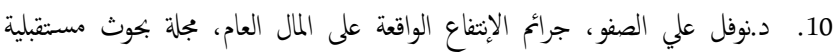

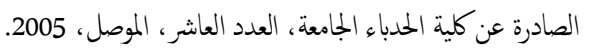

5.4 القوانين والقرارات

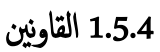

\begin{tabular}{|c|c|}
\hline القانون المدني العراقي رقٍ (40) لسنة 1951 ـ & .1 \\
\hline قانون بيع وتصحيح صنف الأراضي الأميرية رق (51) لسنة 1959. & .2 \\
\hline قانون العقوبات العراقي رق(111) لسنة 1969. & .3 \\
\hline قانون توحيد أصناف أراضي الدولة رقٍ (53) لسنة 1976. & .4 \\
\hline قانون إدارة البلديات في إقليم كوردستان العراق رقٌ (69) لسنة 1993. & .5 \\
\hline من قانون الطرق العامة رق (35) لسنة 2002 ـ & 6 \\
\hline قانون الاستثمر في إقليم كوردستان رث (4) لسنة 2006. & .7 \\
\hline نون تأمين السكن لمواطني إقليم كردستان العراق رق (7) لسنة 008 & .8 \\
\hline م & \\
\hline
\end{tabular}




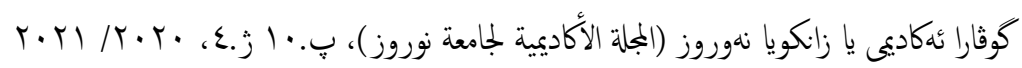

45. ت تقابلها المادة (171) من القانون المدني المصري.

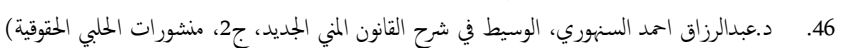

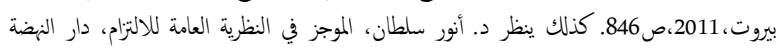

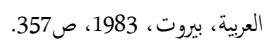

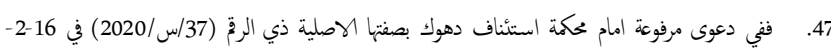

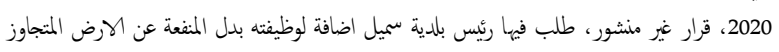

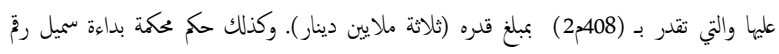

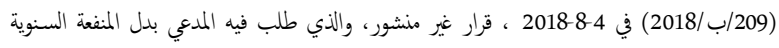

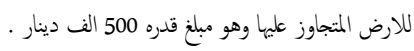

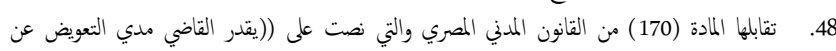

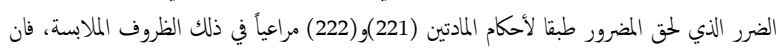

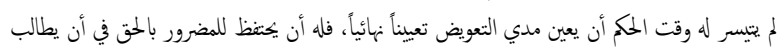
خلال مدة معينة بإعادة النظر في التقدير )).

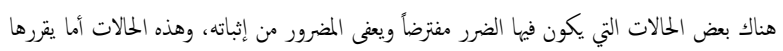

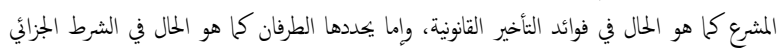

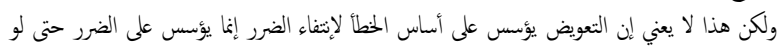

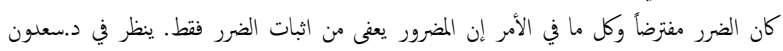

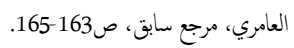

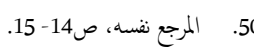

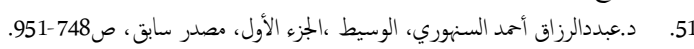

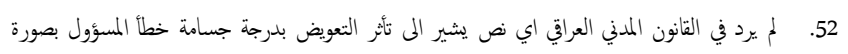

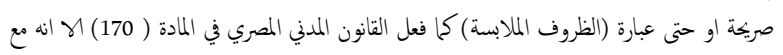

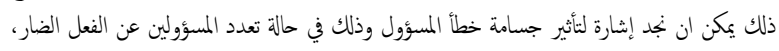

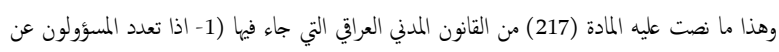

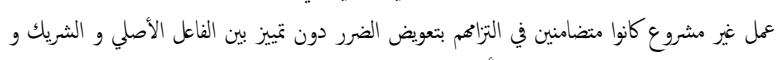

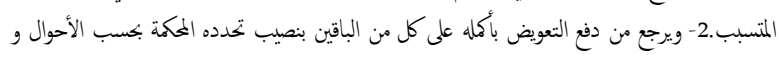

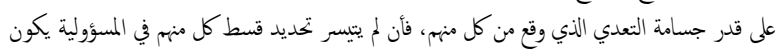
التوزيع عليهم بالتنساوي). 53. ينظر دمنذر الضضل، النظرية العامة للالتزامات، الجزء الأول، دار الثقافة للنشر والثوزيع، عمان، 1996، ص -432- 444. 54. نصت الفقرة (2) من المادة (212) من القانون المدني العراقي على إنه ( فن احدث ضررأ وهو في حالة

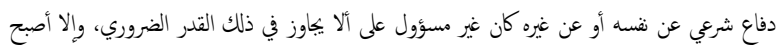
ملزما بتعويض تراعى فيه متضضياة العالة).

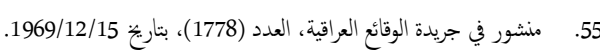
56. انظر د.غني حسون طه، الوجيز في النظرية العامة للالتزامات- مصادر الكالتزام ،مطبعة المعارف، بغداد،

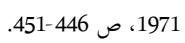
57. د.جبار صابر طه، أساس المسؤلية المدنية عن العمل غير المشروع بين الخطأ والضرر، دار الكتب

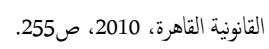

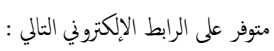
http://www.almothaqaf.com/qadayaama/qadayama-16/903431 . $2020 / 6 / 11$ د.جبار صابر طه، مرجع سابق، ص 257 .
أنظر في النقرة (خامساً) من المادة (2) من قانون حاية وتخسين البيئة العراقي رخة (27) لسنة 2009،

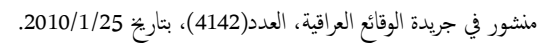

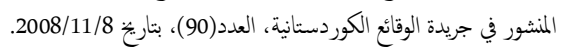
17.

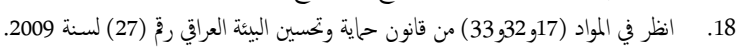

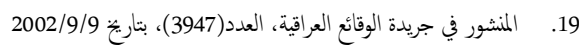

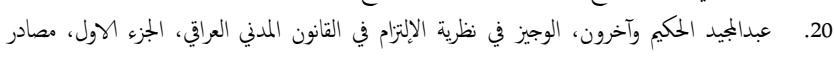

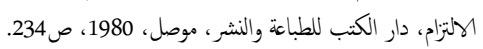

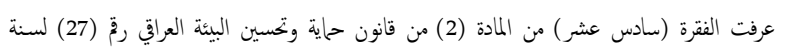

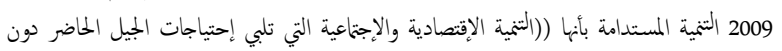

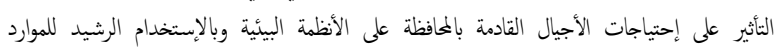
الطبيعة)). د.براء منذر كمال عبداللطيف وسرى حاتم بجيد عبداللطيف، دور التشريعات الخاصة بالتخطيط

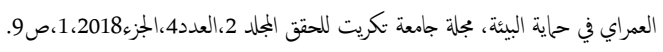

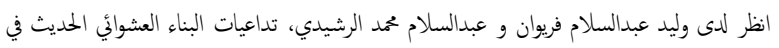

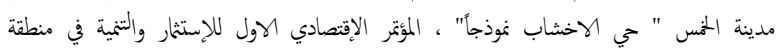

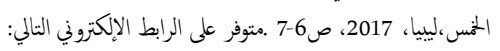
http://ecidiko.elmergib.edu.ly/papers/ECIDIKO2017-022\%20P\%20.pdf آخر زيارة (2020/4/4).

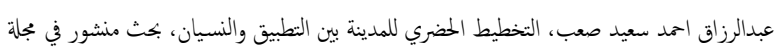

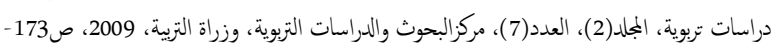

175

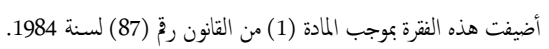

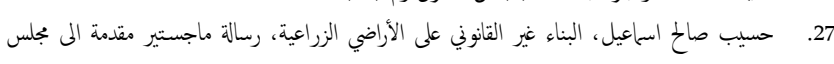

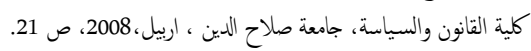

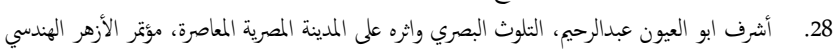

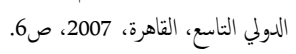
29. د.اسراء موفق رجب، التلوث البصري في مدينة بغداد "السكن العشوائي في حي السلام نموذجاً، مجلة

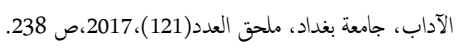
30. ايمان محود الدسوقي، مدخل التنظيم البيئي ومشكلات شباب المداد المناطق العشوائية، دارالوفاء، الاسكندرية، 2016، ص29.

31. السكن العشوائي يساعد على انتشار الامراض والجريمة، تقرير منشور في الانترنت على الرابط التالي:

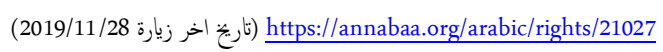
32. د.ممد فاضل يوسف، دور الشرطة في موابجة مشاكل المناطق العشوائية، دار النهة العربية، القاهرة، 2016، ص64. 3.

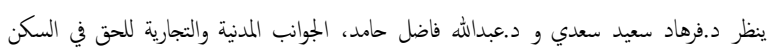

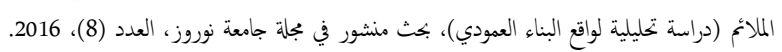

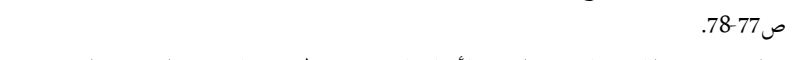
ينظر د.حسن طالب، المدينة والجريمة، الأحياء الفوضوية في النسيج العمراني الحضري والجريمة، دار

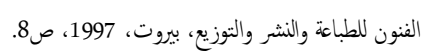

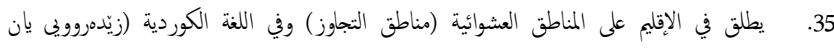

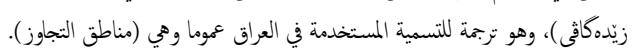

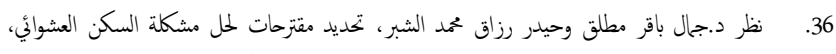

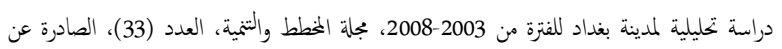

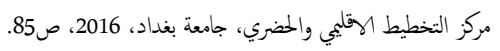

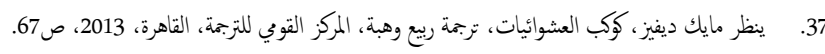

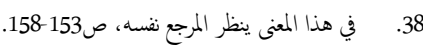

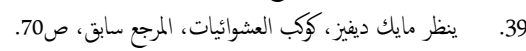

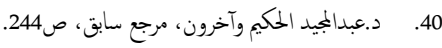

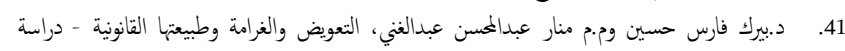

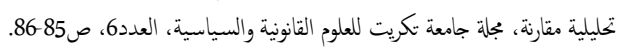

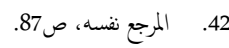
43. د.مصطنى مرعي، المسؤولية المدنية في القانون المصري، الطبعة الثانية، مطبعة الاعتماد، القاهرة، 1994، ص29. 44. د.سعدون العامري، التعويض عن الضرر في المسؤولية التصرية، مركز البحوث القانونية، وزارة العدل، بغداد، 1981، صنان. (149. 